\title{
Immunomodulatory effects of the ether phospholipid edelfosine in experimental autoimmune encephalomyelitis
}

\author{
Abramowski, Pierre ; Steinbach, Karin ; Zander, Axel R ; Martin, Roland
}

\begin{abstract}
The 2-lysophosphatidylcholine analog edelfosine induces apoptosis in highly proliferating cells, e.g. activated immune cells. We examined mechanisms of action of edelfosine on immune functions in experimental autoimmune encephalomyelitis, a well-accepted animal model for multiple sclerosis. We observed activated caspase-3 expression in lymphoid organs and the central nervous system; however, edelfosine did not induce global apoptosis. Edelfosine improved the disease course and led to reduced frequencies of CD4(+) T cells infiltrating into the central nervous system. Our data suggest edelfosine as an interesting treatment candidate for multiple sclerosis.
\end{abstract}

DOI: https://doi.org/10.1016/j.jneuroim.2014.07.007

Posted at the Zurich Open Repository and Archive, University of Zurich

ZORA URL: https://doi.org/10.5167/uzh-99616

Journal Article

Accepted Version

Originally published at:

Abramowski, Pierre; Steinbach, Karin; Zander, Axel R; Martin, Roland (2014). Immunomodulatory effects of the ether phospholipid edelfosine in experimental autoimmune encephalomyelitis. Journal of Neuroimmunology, 274(1-2):111-24.

DOI: https://doi.org/10.1016/j.jneuroim.2014.07.007 

4

\section{Immunomodulatory effects of the ether phospholipid edelfosine in experimental} autoimmune encephalomyelitis (1) Pierre Abramowski ${ }^{\mathrm{a}, \mathrm{b}}$, Karin Steinbach ${ }^{\mathrm{a}, \mathrm{c}}$, Axel R. Zander ${ }^{\mathrm{d}}$, Roland Martin ${ }^{\mathrm{a}, \mathrm{e}_{*}}$ (1) (1)

${ }^{a}$ Institute for Neuroimmunology and Clinical MS Research (inims), Center for Molecular Neurobiology (ZMNH), University Medical Center Hamburg-Eppendorf, Falkenried 94, 20251 Hamburg, Germany

${ }^{\mathrm{b}}$ Research Department Cell and Gene Therapy, Clinic for Stem Cell Transplantation, University Medical Center Hamburg-Eppendorf, Martinistr. 52, 20246 Hamburg, Germany ${ }^{c}$ Department of Pathology and Immunology, Faculty of Medicine, University of Geneva, 1 Rue Michel Servet, 1211 Geneva, Switzerland

${ }^{d}$ Department for Stem Cell Transplantation, University Cancer Center Hamburg (UCCH), Martinistr. 52, 20246 Hamburg, Germany

${ }^{\mathrm{e}}$ Neuroimmunology and MS Research (nims), Department of Neurology, University Hospital Zurich, Frauenklinikstrasse 26, 8091 Zurich, Switzerland

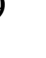

1 * Address correspondence to R. Martin, Neuroimmunology and MS Research, Department of Neurology, University Hospital Zurich, Frauenklinikstrasse 26, 8091 Zurich, Switzerland. Tel.: +41 4425511 25, Fax: +41 44255 8064, E-mail address: roland.martin@ usz.ch 


\section{$1 \quad$ Abstract}

2

3 The 2-lysophosphatidylcholine analog edelfosine induces apoptosis in highly proliferating

4 cells, e.g. activated immune cells. We examined mechanisms of action of edelfosine on 5 immune functions in experimental autoimmune encephalomyelitis, a well-accepted animal 6 model for multiple sclerosis. We observed activated caspase-3 expression in lymphoid organs 7 and the central nervous system, however, edelfosine did not induce global apoptosis. 8 Edelfosine improved the disease course and led to reduced frequencies of $\mathrm{CD} 4^{+} \mathrm{T}$ cells 9 infiltrating into the central nervous system. Our data suggest edelfosine as an interesting 10 treatment candidate for multiple sclerosis. 


\section{Introduction}

3 Apoptotic cell death is an elementary cellular response and involves the sequential activation

4 of caspases. The stress-inducible, intrinsic apoptotic pathway involves cytochrome c release 5 from mitochondria (Liu et al., 1996). The extrinsic pathway is induced by pro-apoptotic and 6 pro-inflammatory cytokines, e.g. FasL, TRAIL and TNF- $\alpha$, respectively, which induce the 7 intracellular formation of specific death-inducing signaling complexes (DISCs) after binding to death domain receptors (Micheau and Tschopp, 2003; Scaffidi et al., 1999). Downstream caspases, e.g. caspase-3, are cleaved to execute cell death. Importantly, elimination of cells via apoptosis does not lead to inflammation or immune activation. Therefore, approaches to induce apoptosis in deregulated, e.g. self-reactive immune cells have been considered to treat autoimmune diseases, for instance multiple sclerosis (MS).

Many potentially pathogenic factors and disease mechanisms have been examined in animal models, particularly in experimental autoimmune encephalomyelitis (EAE) (Raine et al., 1980), and both animal and human studies point to a central role for autoreactive CD4 ${ }^{+} \mathrm{T}$ cells in MS pathology (Sospedra and Martin, 2005). $\mathrm{CD}^{+} \mathrm{T}$ cells are present in central nervous system (CNS) and cerebrospinal fluid (CSF) cellular infiltrates in both MS and EAE (Martin et al., 1990; Ota et al., 1990; Pettinelli and McFarlin, 1981; Richert et al., 1983). Further, albeit indirect evidence for their role stems from the observation that a large fraction of the genetic risk of MS is conferred by HLA-class II alleles of the HLA-DR15 haplotype (Hillert and Olerup, 1993; Jersild et al., 1973). Recently published large genome-wide association studies show over 130 single nucleotide polymorphisms besides HLA-DR as risk alleles for MS (Beecham et al., 2013; Sawcer et al., 2011), and interestingly many of these are involved in T cell activation and function (Lundmark et al., 2007; McElroy and Oksenberg, 2008). Following priming with (auto)antigens to potentially autoreactive $\mathrm{CD}^{+} \mathrm{T}$ cells in the periphery, activated $\mathrm{CD} 4^{+} \mathrm{T}$ cells transmigrate across the blood brain barrier (BBB) and the 
1 blood CSF barrier (Cannella and Raine, 1995). Next, T cells are locally reactivated by antigen

2 presenting cells within the CNS (Flügel et al., 2001). Subsequently, a number of immune cells

3 including those of the innate (neutrophils, macrophages, dendritic cells (DCs), natural killer

4 (NK) cells) and adaptive ( $\mathrm{CD}^{+}$and $\mathrm{CD}^{+} \mathrm{T}$ cells, B cells) immune system (Franciotta et al., 2008; Hauser et al., 2008; Lucchinetti et al., 1996) are recruited and form focal inflammatory

6 lesions (Simpson et al., 1998). Immunodominant peptides of myelin proteins, e.g. myelin 7 oligodendrocyte glycoprotein (MOG) peptide $\mathrm{MOG}_{(35-55)}$, are used to induce chronic EAE in 8 C57BL/6 mice, whereas relapsing-remitting EAE (RR-EAE) in SJL mice follows the injection of proteolipid protein (PLP) peptide $\mathrm{PLP}_{(139-154)}$.

The synthetic 2-lysophosphatidylcholine (LPC) analog edelfosine (1-O-octadecyl-2-Omethyl-rac-glycero-3-phosphocholine, ET-18- $\mathrm{OCH}_{3}$ ) was found to induce selective apoptosis in leukemic cells (Diomede et al., 1993; Mollinedo et al., 1993). In contrast to other cytotoxic drugs edelfosine does not target the DNA and it does not directly interfere with the formation and function of the cellular replication machinery. Edelfosine binds to Fas/CD95 in a lipid raft-mediated process thereby exerting its cytotoxic activity (Gajate and Mollinedo, 2001; van der Luit et al., 2002). Detailed mechanistic studies have demonstrated that edelfosine-treated Jurkat leukemic $\mathrm{T}$ cells undergo apoptosis following recruitment of DISCs into lipid rafts (Gajate et al., 2009). Edelfosine accumulates in the inner leaflet of the plasma membrane in lipid rafts, which in turn induces the clustering of rafts and the recruitment of Fas into rafts with subsequent translocation of Fas, FADD and caspase- 8 into rafts, DISC formation and activation of caspase- 8 to induce apoptosis in the absence of FasL. Normal, resting cells are not able to take up significant amounts of edelfosine (Gajate et al., 2000). Additionally, edelfosine may accumulate in lipid rafts within the plasma membrane followed by endocytosis and translocation to the intracellular location of the CTP:phosphocholine cytidylyltransferase (CCT), the endoplasmic reticulum (ER) (Clement and Kent, 1999; van der Luit et al., 2007, 2002). Here, edelfosine may inhibit the biosynthesis of 
1 phosphatidylcholine (PC) leading to mitotic arrest and apoptosis (Boggs et al., 1995; Van Der

2 Luit et al., 2003). This effect was found in exponentially growing cells, which require high

3 amounts of PC, while normal quiescent cells were not affected (van der Sanden et al., 2004;

4 Zerp et al., 2008). The relative contribution of each mechanism may depend on the cell type

5 and the concentration of edelfosine (Mollinedo et al., 1997; Tsutsumi et al., 1998; Zoeller et

6 al., 1995). Thus, alkyl lysophospholipids like edelfosine may affect several cellular processes,

7 probably with cell type-dependent emphasis but with the joint outcome of apoptosis 8 induction.

9 Due to its immunomodulatory properties and its oral availability edelfosine had already been examined as a treatment for MS in the past (Klein-Franke and Munder, 1992; Munder and Westphal, 1990). Although not performed according to today's standards exploratory clinical trials demonstrated the drug's excellent safety profile. Parallel EAE studies, mostly with rats, but also with mice described a beneficial effect of edelfosine treatment on clinical outcome (Baker et al., 1991; Chabannes et al., 1992; Klein-Franke and Munder, 1992; Kovarik et al., 1995). So far, however, functional investigations on edelfosine-induced modifications of cellular responses in the context of EAE are limited. We therefore wanted to reassess and expand prior work in the EAE model to examine in more detail the mechanism/s of action of edelfosine as a potential treatment in autoimmune diseases, for instance MS.

\section{Materials and Methods}

\subsection{Ethics statement}

All animal experiments were performed in accordance with the guidelines of the local authorities (Behörde für Soziales, Gesundheit und Verbraucherschutz Hamburg; G22/08). 
2 For in vivo applications, edelfosine (Medmark, Oberhaching, Germany) was dissolved in aqua

\subsection{Preparation of edefosine} ad injectabilia and diluted with PBS (PAA, Pasching, Austria). The diluted edelfosine was stored at $-20^{\circ} \mathrm{C}$ and thawed on the day of application. The injected edelfosine dose per mouse was $1 \mathrm{mg} / \mathrm{kg}, 10 \mathrm{mg} / \mathrm{kg}, 15 \mathrm{mg} / \mathrm{kg}$ and $25 \mathrm{mg} / \mathrm{kg}$ edelfosine. Edelfosine was applied by intraperitoneal injection or by gavage.

\subsection{Mice}

C57BL/6J mice were purchased from the Jackson Laboratory and bred by the animal facility of the University Medical Center Hamburg Eppendorf. SJL/JHan ${ }^{\mathrm{TM}} \mathrm{Hsd}$ mice were purchased from Harlan Laboratories, Indianapolis, IN, USA.

\subsection{Induction of EAE}

For EAE experiments C57BL/6 mice or SJL mice were housed in "individually ventilated cages (IVC)"-racks at least one week prior to the active induction of EAE. On the day of immunization mice were injected subcutaneously at two sites of the flanks with $200 \mu \mathrm{g}$ of $\mathrm{MOG}_{(35-55)}(\mathrm{NeoMPS}$, San Diego, CA, USA) or $75 \mu \mathrm{g} / \mathrm{ml}$ of PLP $(139-151)$ (NeoMPS) peptide in incomplete Freund's adjuvant (BD Difco Diagnostics, Sparks, MD, USA) supplemented with $4 \mathrm{mg} / \mathrm{ml}$ Mycobacterium tuberculosis H37 Ra (BD Difco). C57BL/6 mice were injected intravenously with 300 ng of pertussis toxin (Calbiochem Merck, Darmstadt, Germany) on the day of immunization and $48 \mathrm{~h}$ later. SJL mice received a single dose of $200 \mathrm{ng}$ pertussis toxin on the day of immunization. Body weight and clinical score were monitored on a 0 to 5 scale with classifications of disease severity: $0=$ healthy, $1=\operatorname{limp}$ tail, $2=$ ataxia and/or paresis of hind limbs, 3 = paraplegia, $4=$ paraplegia with forelimb weakness, $5=$ moribund or dead. 
2 For preparation of lymph nodes and spleens mice were sacrificed at day 9 after immunization.

3 Single cell suspensions were prepared by mincing the tissue and pushing it through a $40 \mu \mathrm{m}$

4 cell sieve. Cells derived from the spleen were resuspended in $5 \mathrm{ml}$ red blood cell lysis buffer 5

\subsection{Preparation of cells from secondary lymphoid organs and CNS of mice}

$\left(0.15 \mathrm{M} \mathrm{NH}_{4} \mathrm{Cl}, 10 \mathrm{mM} \mathrm{KHCO} 3,0.1 \mathrm{mM} \mathrm{Na}_{2}\right.$ EDTA in $\left.\mathrm{ddH}_{2} \mathrm{O}\right)$ and incubated on ice for 7 min. Cells were resuspended in FACS buffer $\left(0.1 \% \mathrm{BSA}, 0.02 \% \mathrm{NaN}_{3}\right.$ in PBS) or PBS $+1 \%$

FCS if the preparation was followed by recall experiments. At the acute phase of EAE mice were perfused transcardially with $50 \mathrm{ml}$ PBS supplemented with $1 \%$ FCS to prepare the CNS.

Dissected brain and spinal cord were digested for $60 \mathrm{~min}$ at $37^{\circ} \mathrm{C}$ by addition of $1 \mathrm{mg} / \mathrm{ml}$ collagenase I and $0.1 \mathrm{mg} / \mathrm{ml}$ DNase I (both from Roche, Penzberg, Germany) in D-MEM (Gibco, Carlsbad, CA, USA). The cell suspension was passed through a $40 \mu \mathrm{m}$ cell strainer and centrifuged $\left(250 \mathrm{xg}, 10 \mathrm{~min}, 4^{\circ} \mathrm{C}\right)$. Cells were separated from myelin and neurons by Percoll (GE Healthcare, Chalfont St. Giles, UK)-gradient centrifugation (30\%/78\%). CNSinfiltrating cells and microglia were collected from the interface. Cells were resuspended in FACS buffer, centrifuged $\left(550 \mathrm{xg}, 10 \mathrm{~min}, 4^{\circ} \mathrm{C}\right)$ and washed two additional times $(250 \mathrm{xg}, 10$ $\left.\min , 4^{\circ} \mathrm{C}\right)$.

\subsection{Cell culture experiments}

To determine $\mathrm{T}$ cell proliferation by $\left[\right.$ methyl- $\left.{ }^{3} \mathrm{H}\right]$-thymidine incorporation, spleen- and lymph node-derived cells were seeded in 96-well plates (Greiner Bio-One, Frickenhausen, Germany) at $2 \times 10^{5}$ cells/well. Murine cells were cultured in $200 \mu$ of complete mouse medium $(50 \mu \mathrm{M}$ $\beta$-mercaptoethanol, 10\% FCS in RPMI1640 medium, GlutaMAX ${ }^{\mathrm{TM}}$ (Gibco)) supplemented with the disease-relevant peptide $\operatorname{PLP}_{(139-151)}$, a polyclonal anti-CD3 antibody (145-2C11, from eBioscience, San Diego, CA, USA) or mitogenic Concanavalin A (Con A, from SigmaAldrich, St. Louis, MO, USA). 
2 Mice were transcardially perfused with cold PBS followed by $4 \%$ cold PFA (AppliChem, 3 Darmstadt, Germany) in phosphate buffer. Preparation of brain, spinal cord and optic nerves

\subsection{Immunohistochemistry} was followed by post-fixation of the tissue in $4 \%$ PFA in phosphate buffer $\left(30 \mathrm{~min}, 4^{\circ} \mathrm{C}\right)$. The tissue was impregnated 2-3 days in 30\% sucrose in PBS for cryoprotection. Cervical, thoracic and lumbar spinal cord as well as cerebellum and forebrain were separated. The tissue was embedded in Tissue Freezing Medium (Jung, Leica Biosystems, Nussloch, Germany) and frozen in isopentane (Carl Roth, Karlsruhe, Germany). Tissue was stored at $-80^{\circ} \mathrm{C} .12-14 \mu \mathrm{m}$ slices were generated using a cryostat and mounted on glass microslides (Superfrost/Plus from Karl Hecht, Sondheim, Germany). For quantification of Neuronal Nuclei (NeuN)expressing neuronal cells within the cervical spinal cord $14 \mu \mathrm{m}$ cryosections were rinsed $3 \mathrm{x}$ with PBS and incubated for $2 \mathrm{~h}$ at RT in blocking solution (0.1\% Triton X 100 (Carl Roth), 10\% normal donkey serum (Chemicon, Billerica, MA, USA) in PBS). Subsequently, primary anti-NeuN antibody (A60, Millipore, Billerica, MA, USA) was added, and the sections were incubated at $4^{\circ} \mathrm{C}$ over night. The tissue was rinsed $3 \mathrm{x}$ with PBS and incubated with DyLight488-labeled secondary antibody (Jackson ImmunoResearch, Newmarket, UK). AntiNeuN antibody was diluted 1:100 in PBS, the secondary antibody was diluted 1:400 in PBS. For each mouse, six cervical spinal cord sections were selected and two adjacent photographs per ventral horn were made. Quantification was carried out by detection of $\mathrm{NeuN}^{+}$neurons within the ventral horn including the lower motor neurons. Cervical spinal cord sections from age-matched, not-immunized SJL control mice were used to rank EAE-induced neuronal loss and edelfosine-mediated treatment effects. Images were acquired using a Axiovert 40 inverted microscope (Carl Zeiss, Jena, Germany) and analyzed with AxioVision AxioVs40 V 4.6.3.0 software (Zeiss). Photographs were taken with 20x magnification. $\mathrm{NeuN}^{+}$cells were counted and the average number of neurons per section was calculated. 
$2 \mathrm{~T}$ cells were derived from lymph nodes and spleens of SJL mice that were immunized as

3 previously described. T cell proliferation was determined by the incorporation of [methyl- $\left.{ }^{3} \mathrm{H}\right]-$

4 thymidine (Hartmann Analytic, Braunschweig, Germany) after $72 \mathrm{~h}$ of incubation. $16 \mathrm{~h}$

5 before harvesting the cells, $1 \mu \mathrm{Ci}\left[\right.$ methyl $\left.{ }^{3} \mathrm{H}\right]$-thymidine was added to each well. For

6 quantification of beta particle emission the cells were harvested, washed and analyzed by

7 using a beta counter (Wallac, Waltham, MA, USA). The stimulation index (SI) is calculated

\subsection{Flow cytometry}

For the analysis of intracellular cytokines cells were incubated for $4 \mathrm{~h}$ in complete mouse medium supplemented with $100 \mathrm{ng} / \mathrm{ml}$ PMA and $1 \mu \mathrm{g} / \mathrm{ml}$ ionomycin (both from SigmaAldrich). After 1 h $10 \mu \mathrm{g} / \mathrm{ml}$ Brefeldin A (BioLegend, San Diego, CA, USA) was added. For Fc-receptor blocking cells were incubated in FACS buffer supplemented with antiCD16/CD32 antibody (93, eBioscience). CNS-infiltrating leukocytes were quantified using BD Trucount Absolute Counting Tubes (BD Biosciences, San Jose, CA, USA) and anti-CD45 antibody. For intracellular staining of cytokines, but also of activated caspase-3, IC fixation buffer and permeabilization buffer (eBioscience) were used. Staining for Foxp3 was performed according to the Foxp3/Transcription Factor Staining Buffer Set (eBioscience). For exclusion of dead cells from the preparation of CNS-infiltrating immune cells, the LIVE/DEAD Fixable Aqua Dead Cell Stain Kit (Invitrogen, Carlsbad, CA, USA) was used. The following antibodies were used to perform analysis by flow cytometry: anti-CD3PacificBlue (500A2), anti-NK1.1-PE-Cy7 (PK136) and anti-caspase-3-PE (C92-605) from BD Pharmingen (San Diego, CA, USA), anti-CD3-PerCP-Cy5.5 (145-2C11), anti-CD4-FITC (GK1.5), anti-CD8a-PE-Cy7 (53-6.7), anti-CD45-APC-Cy7 (30-F11) from BioLegend, as 
1 well as anti-CD4-APC-eFluor780 (RM4-5), anti-CD4-eFluor450, anti-CD4-PE (GK1.5), anti-

2 CD8a-eFluor450 (53-6.7), anti-CD11b-APC (M1/70), anti-CD11b-FITC (M1/70), anti-

3 CD11c-APC (N418), anti-CD11c-PE-Cy7 (N418), anti-CD25-APC (PC61.5), anti-CD44-

4 APC (IM7), anti-CD45-PE-Cy7 (30-F11), anti-CD45R(B220)-PE-Cy5.5 (RA3-6B2) anti-

5 CD62L-PE-Cy7 (MEL-14), anti-CD69-FITC (H1.2F3), anti-IFN- $\gamma$-PE (XMG1.2), anti-IL-

6 17A-Alexa647 (17B7), anti-Ly-6G-FITC (RB6-8C5), anti-Ly-6G-PE (RB6-8C5) and anti-

7 NK1.1-PE (PK136), all from eBioscience. Data was acquired on an LSRII flow cytometer

8 (BD Biosciences, San Jose, CA, USA) and analyzed with BD FACSDiva and FlowJo (Tree

9 Star, Ashland, OR, USA) software.

\subsection{Statistical analysis}

12 EAE disease courses were analyzed by two-way ANOVA and Bonferroni multiple testing correction (post-hoc analysis) using Prism 5.02 software (GraphPad Software, La Jolla, CA, USA). In graphs representing the EAE disease courses treatment effects were indicated by asterisks. Significant differences between groups were described in respective figure legends after Bonferroni post-hoc analysis. Cumulative disease scores and neuronal quantification by immunohistochemistry were analyzed by 1-way ANOVA followed by Bonferroni post-hoc test with asterisks indicative of significant differences between groups. Moreover, data generated by flow cytometry for leukocyte subsets derived from EAE-induced mice were evaluated by Bonferroni post-hoc analysis after 1-way ANOVA. With regard to lymph nodes and spleen-derived subsets, frequencies were normalized and expressed as fold-changes in order to allow merging of two independent experiments. Ex vivo proliferation assays of murine lymph node cells were analyzed by 1-way ANOVA and Bonferroni post-hoc analysis, whereas results of proliferation assays of spleen-derived cells were tested by non-parametric Kruskal-Wallis test followed by Dunns post-hoc analysis. 


\section{3. Results}

\subsection{Edelfosine treatment improves clinical symptoms in the EAE mouse model}

6 In a first dose finding study we examined edelfosine in the chronic, MOG peptide-induced

7 EAE model in C57BL/6 mice (Fig. 1A). From the day of immunization (day 0) mice were administered with equal volumes of edelfosine or PBS by gavage on a daily basis. The PBStreated control cohort developed first signs of EAE at day 12 after immunization reaching maximum EAE score at day 18. This acute phase of disease was shifted to later days if mice were treated with edelfosine. In contrast to higher doses the treatment of mice with $10 \mathrm{mg} / \mathrm{kg}$ edelfosine did not lead to apparent side effects, e.g. tremor, inactivity, and slowed motion, but resulted in a reduced EAE score. Administration of edelfosine led to a significant amelioration of EAE when comparing PBS-treated controls and mice treated with $10 \mathrm{mg} / \mathrm{kg}$ edelfosine. We therefore continued with $10 \mathrm{mg} / \mathrm{kg}$ as effective edelfosine concentration. In a subsequent preventive approach we studied the effects of edelfosine on RR-EAE disease course in SJL mice. SJL mice were immunized with the $\operatorname{PLP}_{(139-151)}$ peptide (day 0). Notably, the treatment of mice with edelfosine from day 5 every other day by i.p. injection did not result in significant differences between cohorts regarding treatment effects in the course of EAE (Fig. 1B) and regarding cumulative disease scores (Fig. 1D) despite a trend to improved disease scores. To investigate the therapeutic effectiveness of edelfosine on EAE, SJL mice were immunized and disease scores were monitored. Mice showed first distinct and evenly distributed signs of EAE across groups at day 11. Treatment with PBS, $1 \mathrm{mg} / \mathrm{kg}$ edelfosine, or $10 \mathrm{mg} / \mathrm{kg}$ edelfosine was started at this day and continued until day 45 (Fig. 1C). Clinical scores upon edelfosine treatment were reduced, however, the treatment effect did not reach statistical significance despite a clear tendency towards reduced cumulative disease scores in 
1 edelfosine-treated cohorts (a significant treatment effect with significant differences between

2 PBS-treated and $10 \mathrm{mg} / \mathrm{kg}$ edelfosine-treated groups was detectable for the therapeutic

3 treatment setting if EAE scores were analyzed until day 20), summarized in Fig. 1E.

4 However, the preventive edelfosine treatment of SJL mice was effective when started at day

50 . Immediately after EAE induction PBS, $1 \mathrm{mg} / \mathrm{kg}$ edelfosine, or $10 \mathrm{mg} / \mathrm{kg}$ edelfosine was

6 administered and repeated on a daily basis by i.p. injection. The progression of disease course

7 was monitored until day 40 (Fig. 2A). A significant treatment effect was found in this

8 preventive setting. Interestingly, differences emerged at the first disease bout from day 12 to

914 as well as at the first EAE relapse from day 28 to 33 . A significant treatment effect was

10 also detected when the cumulative disease scores of the three cohorts were analyzed (Fig.

$112 \mathrm{2B}$ ). Differences in post-hoc analysis were found for the comparison of PBS-treated controls

12 to $10 \mathrm{mg} / \mathrm{kg}$ edelfosine-treated mice.

3.2 Preventive edelfosine treatment increases activated caspase-3 expression in the preclinical phase of RR-EAE

For a detailed analysis of the impact of edelfosine on different immunological parameters immunized SJL mice received PBS, $1 \mathrm{mg} / \mathrm{kg}$ edelfosine, or $10 \mathrm{mg} / \mathrm{kg}$ edelfosine by i.p. injection from the day of immunization (day 0) on a daily basis until day 9. There were no differences in absolute cell numbers in spleens as well as draining lymph nodes during the preventive treatment (data not shown). Furthermore, neither immune cell subset derived from spleens nor subsets derived from lymph nodes displayed any edelfosine treatment-associated changes in frequencies compared to PBS-treated controls $\left(\mathrm{CD}^{+} \mathrm{T}\right.$ cells, B220 ${ }^{+} \mathrm{B}$ cells, CD11 ${ }^{+} \mathrm{CD} 11 \mathrm{c}^{-}$macrophages, Ly-6G ${ }^{+} \mathrm{CD} 11 \mathrm{~b}^{+}$neutrophils, $\mathrm{CD} 11 \mathrm{~b}^{-} \mathrm{CD} 11 \mathrm{c}^{+} \mathrm{B} 220^{-}$myeloid 
1 differences in global $\mathrm{CD}^{+}$and $\mathrm{CD}^{+} \mathrm{T}$ cells were observed (Fig. 3A and -B), while naïve

$2 \mathrm{CD} 4{ }^{+} \mathrm{CD} 62 \mathrm{~L}^{\text {high }} \mathrm{CD} 44^{\text {low }} \mathrm{T}$ cells increased in lymph nodes upon edelfosine treatment (Fig.

3 3C). No differences were seen between frequencies of $\mathrm{CD}^{+} \mathrm{CD} 69^{+}$or $\mathrm{CD} 4^{+} \mathrm{CD} 25^{+} \mathrm{T}$ cells

4 isolated from spleens and lymph nodes in either group or for the respective $\mathrm{CD} 8^{+} \mathrm{T}$ cell

5 populations (data not shown). Thus, edelfosine treatment did not influence frequencies of $\mathrm{T}$

6 cells in the periphery, which express strong activation signals. As an additional $\mathrm{CD} 4^{+} \mathrm{T}$ cell

7 subset $\mathrm{CD} 4^{+} \mathrm{CD} 25^{+} \mathrm{Foxp}^{+}$natural regulatory $\mathrm{T}$ cells (nTregs) were identified in spleens and

8 lymph nodes of EAE-induced mice by gating on $\mathrm{CD} 4^{+} \mathrm{CD} 25^{+}$populations excluding $\mathrm{CD} 69^{+}$

9 events. The comparison of nTreg frequencies from PBS-treated and edelfosine-treated cohorts

10 in either spleens or lymph nodes did not indicate treatment-dependent changes (data not

11 shown). The treatment of EAE-induced mice with edelfosine was not found to have an impact

12 on IFN- $\gamma$ or IL-17-producing $\mathrm{CD}^{+}$as well as $\mathrm{CD}^{+}$lymphocyte subset frequencies in the

spleen or lymph nodes compared to controls (data not shown). Hence, it does not appear that

edelfosine leads to global perturbations of the peripheral immune system.

Since it had previously been demonstrated that elimination of $\mathrm{T}$ cells from the brain in the

EAE model involves apoptosis (Schmied et al., 1993), and since this is the presumed mechanism of action of edelfosine, we wanted to examine this aspect by caspase- 3 activation as an early step of apoptosis upon edelfosine treatment. Therefore, $\mathrm{CD} 4^{+}$and $\mathrm{CD} 8^{+} \mathrm{T}$ cells prepared from spleens and lymph nodes of EAE-induced mice that were treated with PBS or edelfosine were stained for caspase-3 activation (Fig. 4A and -B). As edelfosine is described as acting primarily on proliferating cells, CD69 was used to specifically determine activated T cells. In spleens the treatment of EAE-induced mice with $10 \mathrm{mg} / \mathrm{kg}$ edelfosine led to a significant increase in frequencies of $\mathrm{CD}^{+}\left(1.70\right.$-fold) and $\mathrm{CD}^{+}(1.99$-fold) $\mathrm{T}$ cells with activated caspase-3 compared to PBS-treated, immunized mice (Fig. 4C). $10 \mathrm{mg} / \mathrm{kg}$ edelfosine also resulted in a 1.59-fold increase in frequencies of $\mathrm{CD}^{+} \mathrm{T}$ cells with activated 
$1 \mathrm{CD} 9^{+} \mathrm{CD}^{+} \mathrm{T}$ cell frequencies were elevated in spleens after $10 \mathrm{mg} / \mathrm{kg}$ edelfosine treatment

2 (2.04-fold compared to PBS, 1.95 -fold compared to $1 \mathrm{mg} / \mathrm{kg}$ edelfosine).

3

3.3 Edelfosine treatment does not compromise the proliferative capacity of $T$ cells in $R R$ -

$E A E$

6

Spleen and lymph node cells of edelfosine-treated mice retained their proliferative capacity as shown in ex vivo proliferation experiments. Of interest, ex vivo activation with $\operatorname{PLP}_{(139-151)}$ appears to indicate an edelfosine dose-dependent effect on proliferation in vivo (Fig. 5A). Increased SIs were found at higher doses of edelfosine (Fig. 5B). This phenomenon is caused by the greater reduction of background proliferation (in the absence of antigenic stimulus in vitro) as a result of edelfosine treatment of mice (Fig. 5A and -B).

3.4 Edelfosine treatment reduces CNS-infiltrating $T$ cell frequencies and leads to expression of activated caspase-3

The acute phase of EAE is clinically apparent through maximal impairment of motor function. Pathologically, this period is characterized by a marked infiltration of immune cells from the periphery into the CNS. In this set of experiments SJL mice were immunized with $\operatorname{PLP}_{(139-151)}$ to induce EAE. Mice were either treated with PBS, $1 \mathrm{mg} / \mathrm{kg}$ edelfosine, or 10 $\mathrm{mg} / \mathrm{kg}$ edelfosine from the day of immunization on a daily basis. PBS-treated mice displayed a maximum mean EAE score of $2.67 \pm 0.51$ at day 14 after immunization (Supplementary Fig. 2A). By contrast, mice treated with $1 \mathrm{mg} / \mathrm{kg}$ or $10 \mathrm{mg} / \mathrm{kg}$ edelfosine showed a considerably lower clinical score (1.63 \pm 0.42 and $0.13 \pm 0.13$, respectively). At day 15 spinal cords and brains were prepared to analyze cellular infiltration of the CNS by flow cytometry 
1 cell numbers in the CNS were detected between PBS-treated mice and at both doses of

2 edelfosine (Supplementary Fig. 2B). $10 \mathrm{mg} / \mathrm{kg}$ edelfosine resulted in reduced frequencies (-

3 1.71-fold) of $\mathrm{CD}^{+} \mathrm{T}$ cells in the CNS (Supplementary Fig. 2D) and at the same time

4 increased frequencies (6.46-fold) of neutrophils compared to PBS controls. CD4 ${ }^{+} \mathrm{T}$ cell

5 frequencies were reduced at $10 \mathrm{mg} / \mathrm{kg}$ edelfosine in comparison to $1 \mathrm{mg} / \mathrm{kg}$ edelfosine or 6 control (-1.17-fold) (Fig. 6). In contrast, no differences were determined for $\mathrm{CD}^{+} \mathrm{T}$ cells

7 (Fig. 6). Compared to PBS edelfosine did not alter the frequency of CNS-infiltrating nTregs 8 (Fig. 6) or IFN- $\gamma$-producing $\mathrm{CD}^{+} \mathrm{T}$ cells, while IFN- $\gamma$-producing $\mathrm{CD}^{+} \mathrm{T}$ cells were reduced

9 (Fig. 7). Edelfosine led to a significant treatment effect in view of IL-17-producing $\mathrm{CD}^{+}{ }^{+} \mathrm{T}$ 10 cells, but no differences could be detected between groups after post-hoc analysis (Fig. 7).

11 Finally, the impact of edelfosine treatment on apoptosis induction, i.e. caspase- 3 activation, in 12 CNS-infiltrating T lymphocyte subsets was investigated (Fig. 8), and a clear increase of

\subsection{Preventive edelfosine treatment reduces neuronal loss in acute RR-EAE}

To detect and quantify the damage of neurons within the cervical spinal cord of EAE-affected SJL mice during the acute disease phase, tissue sections were prepared for immunohistochemistry. Sections were stained with antibodies against the neuron-specific nuclear protein NeuN (Fig. 9). Compared to controls a significant decrease in $\mathrm{NeuN}^{+}$neurons was detected in EAE-induced, PBS-treated mice. Neuronal loss could be reduced markedly by treatment with $1 \mathrm{mg} / \mathrm{kg}$ or $10 \mathrm{mg} / \mathrm{kg}$ edelfosine. 
3 The main findings of our study are the clinical amelioration of RR-EAE by systemic

\section{Discussion}

edelfosine treatment and, at the level of its mechanism, the increase of apoptosis-prone, activated caspase-3-expressing $\mathrm{CD}^{+} \mathrm{T}$ cells within the CNS of EAE-induced mice. Additionally, proliferative $\mathrm{T}$ cell responses upon recall stimulations were not impaired, and neuronal damage was decreased upon treatment. Our results, therefore, translate in vitro generated mechanistic knowledge about edelfosine into the in vivo settings.

$10 \mathrm{mg} / \mathrm{kg}$ edelfosine was identified to be effective in ameliorating chronic-progressive EAE without causing side effects after preventive, oral administration. Additionally, EAE incidences were reduced upon edelfosine treatment confirming observations in Biozzi $\mathrm{AB} / \mathrm{H}$ mice (Baker et al., 1991). In accordance with these previous EAE trials in Biozzi AB/H mice, $10 \mathrm{mg} / \mathrm{kg}$ edelfosine treatment resulted in delayed onset of EAE. The beneficial effect of 10 $\mathrm{mg} / \mathrm{kg}$ edelfosine was subsequently validated in the relapsing-remitting EAE model in SJL mice. As experiments by Klein-Franke and Munder pointed to the effectiveness of treatment initiation from day 5 after immunization, SJL mice received edelfosine from day 5 in a second EAE experiment (Klein-Franke and Munder, 1992). Additionally, dose rates were limited by edelfosine treatment only every other day. Interestingly, pharmacokinetic studies in rats reported a rapid uptake and distribution of a liposomal formulation of an edelfosine L-isomer into tissues (time to reach highest concentrations: 0.25 to $8 \mathrm{~h}$, half-lives were $13.1 \mathrm{~h}$ in blood and $14 \mathrm{~h}$ in spleens) (Bhamra et al., 2003). Furthermore, approximately $96 \%$ of edelfosine was absorbed in the first 24 hours after oral treatment of rats (Kötting et al., 1992). These and our data denote that edelfosine given every $48 \mathrm{~h}$ may not be suitable for maintaining a local concentration necessary to interfere with the priming of autoreactive immune cells in EAE and that intervals need to be reduced to balance clearance of edelfosine from peripheral lymphoid organs. In the preventive setting, daily treatment was adequate, probably by 
1 sustaining edelfosine concentrations in peripheral lymphoid organs, which were effective to

2 interfere with immune cell functions. These results suggest that edelfosine acts not only via

3 modulation of $\mathrm{T}$ cell priming for EAE induction but also on induction of relapses.

$4 \quad$ LPC and its synthetic analogs were initially described to enhance the phagocytic activity of

5 macrophages (Burdzy et al., 1964; Munder et al., 1969, 1966). Therefore they were assigned

6 an immunomodulatory role in defense mechanisms of the immune system. Since MS but also

7 EAE are mediated by myelin-specific encephalitogenic T cells (Coles et al., 1999; Martin et

8 al., 1992; Wekerle et al., 1986; Zamvil and Steinman, 1990), treatment effects on T cell

9 priming in secondary lymphoid tissues were determined. Edelfosine does not act by

10 indiscriminately eliminating cells in secondary lymphoid organs that are indispensable for

11 priming and triggering antigen-specific immunity, i.e. edelfosine does not lead to major

12 perturbations or loss of peripheral immune cells. Importantly, edelfosine treatment did not

13 induce the ablation of nTregs from peripheral lymphoid organs. Tregs are thought to be

14 involved in preventing the development of autoimmune diseases, and changes in number and

15 function were also reported in MS (Haas et al., 2005; Viglietta et al., 2004) and EAE

16 (McGeachy et al., 2005; Yu et al., 2005; Zhang, 2004). The frequencies of nTregs after

17 repeated edelfosine treatment were not altered indicating that it does not affect nTreg-

18 mediated peripheral tolerance mechanisms. To confirm the previously shown apoptosis

19 induction by edelfosine the frequencies of caspase-3-activated $\mathrm{CD}^{+}$and $\mathrm{CD} 8^{+} \mathrm{T}$ cells were

20 evaluated. The ex vivo analysis of peripheral T cells from edelfosine-treated, EAE-induced

21 mice demonstrated increased frequencies of apoptosis-prone $\mathrm{T}$ cells.

22 To further delineate the influence of daily edelfosine treatment on the functional properties of

23 spleen and lymph node-derived T cells, cells were used in ex vivo restimulation experiments.

24 Repetitive edelfosine treatment of mice was not found to interfere with the capacity of

25 lymphocytes to proliferate and to respond to inflammatory cues independent of the stimulus

26 (mitogenic, polyclonal or antigen-specific). Upon each of the stimuli no significant change in 
1 proliferation was observed by daily edelfosine treatment confirming that edelfosine does not

2 compromise the proliferative potential of $\mathrm{T}$ cells. These findings are of practical and

3 translational relevance, since some of the approved immunomodulatory drugs for MS, e.g.

4 mitoxantrone and alemtuzumab to name two approved drugs, eradicate a wide spectrum of

5 immune cells or broadly inhibit immune function. Such therapies carry the risk of various side

6 effects, among which the increase in susceptibility to infections.

7 In EAE, impairment of motor function is maximal during acute disease, and edelfosine ameliorated the functional deficits as shown by reduced EAE scores. One curious observation is the increase of neutrophils in the CNS of mice receiving $10 \mathrm{mg} / \mathrm{kg}$ edelfosine. While we can only speculate on the causes of this finding, edelfosine crosses the BBB (Arnold et al., 1978; Bhamra et al., 2003; Estella-Hermoso de Mendoza et al., 2009). Drug concentrations that are achieved by administration of $10 \mathrm{mg} / \mathrm{kg}$ edelfosine treatment may be sufficient to induce activation in neutrophils. Neutrophils can be activated in vitro by platelet activating factor (PAF) (Read et al., 1993), and interestingly, PAF is a natural analogue of edelfosine. PAF has been involved in inflammatory processes like neutrophil chemotaxis (Chignard et al., 1979; O'Flaherty et al., 1981). Human neutrophils showed increased cytosolic free $\mathrm{Ca}^{2+}$ concentration mediated by edelfosine binding to PAF-R, but the affinity was 5000 -fold lower compared to PAF (Alonso et al., 1997). Mature peripheral blood neutrophils were not susceptible to edelfosine-induced apoptosis (Mollinedo et al., 1997). Thus, edelfosine may not be able to induce apoptosis but rather to activate neutrophils due to molecular similarities with 21 its physiological counterpart PAF. EAE is mainly mediated by $\mathrm{CD}^{+} \mathrm{T}$ cells, and the specificity of autoreactive $\mathrm{T}$ cells for distinct myelin peptides has been studied in detail (McRae and Miller, 1994; McRae et al., 1995; Pettinelli and McFarlin, 1981). Accordingly, our results emphasize that edelfosine affects the disease-relevant cell population with relative specificity. $\mathrm{CD}^{+} \mathrm{T}$ cells in EAE may have regulatory functions (Friese and Fugger, 2005; 
1 potentially serve as an early source of IFN- $\gamma$ driving Th1-cell differentiation (Das et al.,

2 2011). Treatment with edelfosine led to reduced frequencies of IFN- $\gamma$-producing $\mathrm{CD} 8^{+} \mathrm{T}$

3 cells. In lymphocyte infiltrates of the CNS increased frequencies of $\mathrm{CD}^{+} \mathrm{T}$ cells that

4 expressed activated caspase- 3 after edelfosine treatment were found. These data indicate that

5 either edelfosine is able to induce apoptosis in T cells that have infiltrated the CNS of EAE

6 mice or that the treatment is sufficient to induce apoptosis in T cells in the periphery, which

7 may not prevent those cells from infiltrating the CNS but still leads to disease amelioration.

8 As a summary result edelfosine treatment prevents neuronal loss and ameliorates EAE.

9 Accordingly, immunohistochemical data correlated with disease scores.

10 Recently, we were able to show that edelfosine also inhibits homeostatic proliferation of

11 human $\mathrm{T}$ cells, i.e. proliferation in the absence of an antigenic stimulus (Abramowski et al.,

12 2014). While we did not examine this aspect in detail in the present study, the above

13 observation of higher stimulation indices in antigen-specific proliferation studies due to

14 reduced background proliferation (see Fig. 5B) indicates that inhibition of homeostatic

15 proliferation also applies to murine cells. Further analyses in human T- and B cells

16 demonstrated novel mechanisms of action of edelfosine including the downmodulation of

17 MHC-class II molecules and the induction of type I IFN-associated genes (Abramowski et al.,

18 2014). Here, we complemented these in vitro data with human cells and show the

19 effectiveness of edelfosine treatment in EAE as well as the in vivo induction of apoptosis in

20 disease-relevant $\mathrm{T}$ cell subsets. Our results underscore the potential of edelfosine to treat 21 autoimmune diseases including MS.

\section{Acknowledgments}


1 The authors wish to thank Christian Bernreuther for valuable histological expertise and Stefan

2 Gold for expert advice in the statistical analysis. P.A. was supported by a post-doc grant

3 within the Forschungsförderung Medizin (FFM) program of the Medical faculty of the UMC

4 Hamburg-Eppendorf. P.A. is especially grateful to Gebhard Koch, co-initiator of the ZMNH.

5 The inims was supported by the Gemeinnützige Hertie Stiftung, the Neuroimmunology and

6 MS Research Section (nims) is supported by the Clinical Research Priority Program MS

$7 \quad\left(\mathrm{CRPP}^{\mathrm{MS}}\right)$ of the University Zurich. The funding sources had no role in the conduct of the 8 research.

9

10

11

12

14

\section{References}

Abramowski, P., Otto, B., Martin, R., 2014. The orally available, synthetic ether lipid edelfosine inhibits T cell proliferation and induces a type I interferon response. PLoS One 9, e91970.

Alonso, M.T., Gajate, C., Mollinedo, F., Modolell, M., Alvarez, J., García-Sancho, J., 1997. Dissociation of the effects of the antitumour ether lipid ET-18-OCH3 on cytosolic calcium and on apoptosis. Br. J. Pharmacol. 121, 1364-8.

Arnold, B., Reuther, R., Weltzien, H.U., 1978. Distribution and metabolism of synthetic alkyl analogs of lysophosphatidylcholine in mice. Biochim. Biophys. Acta 530, 47-55.

Baker, D., O’Neill, J.K., Amor, S., Khamashta, M.A., Turk, J.L., 1991. Inhibition of the chronic relapsing experimental allergic encephalomyelitis in the mouse by the alkyllysophospholipid ET-18-OCH3. Int. J. Immunopharmacol. 13, 385-392. 
Beecham, A.H., Patsopoulos, N.A., Xifara, D.K., Davis, M.F., Kemppinen, A., Cotsapas, C., Shah, T.S., Spencer, C., Booth, D., Goris, A., Oturai, A., Saarela, J., Fontaine, B., Hemmer, B., Martin, C., Zipp, F., D’Alfonso, S., Martinelli-Boneschi, F., Taylor, B., Harbo, H.F., Kockum, I., Hillert, J., Olsson, T., Ban, M., Oksenberg, J.R., Hintzen, R., Barcellos, L.F., Agliardi, C., Alfredsson, L., Alizadeh, M., Anderson, C., Andrews, R., Søndergaard, H.B., Baker, A., Band, G., Baranzini, S.E., Barizzone, N., Barrett, J., Bellenguez, C., Bergamaschi, L., Bernardinelli, L., Berthele, A., Biberacher, V., Binder, T.M.C., Blackburn, H., Bomfim, I.L., Brambilla, P., Broadley, S., Brochet, B., Brundin, L., Buck, D., Butzkueven, H., Caillier, S.J., Camu, W., Carpentier, W., Cavalla, P., Celius, E.G., Coman, I., Comi, G., Corrado, L., Cosemans, L., Cournu-Rebeix, I., Cree, B.A.C., Cusi, D., Damotte, V., Defer, G., Delgado, S.R., Deloukas, P., di Sapio, A., Dilthey, A.T., Donnelly, P., Dubois, B., Duddy, M., Edkins, S., Elovaara, I., Esposito, F., Evangelou, N., Fiddes, B., Field, J., Franke, A., Freeman, C., Frohlich, I.Y., Galimberti, D., Gieger, C., Gourraud, P.-A., Graetz, C., Graham, A., Grummel, V., Guaschino, C., Hadjixenofontos, A., Hakonarson, H., Halfpenny, C., Hall, G., Hall, P., Hamsten, A., Harley, J., Harrower, T., Hawkins, C., Hellenthal, G., Hillier, C., Hobart, J., Hoshi, M., Hunt, S.E., Jagodic, M., Jelčić, I., Jochim, A., Kendall, B., Kermode, A., Kilpatrick, T., Koivisto, K., Konidari, I., Korn, T., Kronsbein, H., Langford, C., Larsson, M., Lathrop, M., Lebrun-Frenay, C., Lechner-Scott, J., Lee, M.H., Leone, M.A., Leppä, V., Liberatore, G., Lie, B.A., Lill, C.M., Lindén, M., Link, J., Luessi, F., Lycke, J., Macciardi, F., Männistö, S., Manrique, C.P., Martin, R., Martinelli, V., Mason, D., Mazibrada, G., McCabe, C., Mero, I.-L., Mescheriakova, J., Moutsianas, L., Myhr, K.M., Nagels, G., Nicholas, R., Nilsson, P., Piehl, F., Pirinen, M., Price, S.E., Quach, H., Reunanen, M., Robberecht, W., Robertson, N.P., Rodegher, M., Rog, D., Salvetti, M., Schnetz-Boutaud, N.C., Sellebjerg, F., Selter, R.C., Schaefer, C., Shaunak, S., Shen, L., Shields, S., Siffrin, V., Slee, M., Sorensen, P.S., Sorosina, M., Sospedra, M., Spurkland, 
A., Strange, A., Sundqvist, E., Thijs, V., Thorpe, J., Ticca, A., Tienari, P., van Duijn, C., Visser, E.M., Vucic, S., Westerlind, H., Wiley, J.S., Wilkins, A., Wilson, J.F., Winkelmann, J., Zajicek, J., Zindler, E., Haines, J.L., Pericak-Vance, M.A., Ivinson, A.J., Stewart, G., Hafler, D., Hauser, S.L., Compston, A., McVean, G., De Jager, P., Sawcer, S.J., McCauley, J.L., 2013. Analysis of immune-related loci identifies 48 new susceptibility variants for multiple sclerosis. Nat. Genet. 45, 1353-60.

Bhamra, R., Bolcsak, L.E., Ahmad, I., Schupsky, J., Roberts, P., Stevens, R., Cavanaugh, C., Swenson, C.E., 2003. Activity, pharmacokinetics and tissue distribution of TLC ELL-12 (liposomal antitumor ether lipid) in rats with transplantable, s.c. methylnitrosoureainduced tumors. Anticancer. Drugs 14, 481-6.

Boggs, K.P., Rock, C.O., Jackowski, S., 1995. Lysophosphatidylcholine attenuates the cytotoxic effects of the antineoplastic phospholipid 1-O-octadecyl-2-O-methyl-racglycero-3- phosphocholine. J. Biol. Chem. 270, 11612-8.

Burdzy, K., Munder, P.G., Fischer, H., Westphal, O., 1964. Increase in the phagocytosis of peritoneal macrophages by lysolecitin. Zeitschrift für Naturforschung. Tl. B 19, 111820.

Cannella, B., Raine, C.S., 1995. The adhesion molecule and cytokine profile of multiple sclerosis lesions. Ann. Neurol. 37, 424-35.

Chabannes, D., Ryffel, B., Borel, J.F., 1992. SRI 62-834, a cyclic ether analogue of the phospholipid ET-18-OCH3 displays long-lasting beneficial effect in chronic relapsing experimental allergic encephalomyelitis in the Lewis rat. Comparison with Cyclosporin and (Val2)-dihydrocyclosporin effects in. J. Autoimmun. 199-211. 
1 Chignard, M., Le Couedic, J.P., Tence, M., Vargaftig, B.B., Benveniste, J., 1979. The role of 2 platelet-activating factor in platelet aggregation. Nature 279, 799-800.

3 Clement, J.M., Kent, C., 1999. CTP:phosphocholine cytidylyltransferase: insights into regulatory mechanisms and novel functions. Biochem. Biophys. Res. Commun. 257, $643-50$.

6 Coles, A.J., Wing, M.G., Molyneux, P., Paolillo, A., Davie, C.M., Hale, G., Miller, D., Waldmann, H., Compston, A., 1999. Monoclonal antibody treatment exposes three mechanisms underlying the clinical course of multiple sclerosis. Ann. Neurol. 46, 296-

Das, G., Sheridan, S., Janeway, C.A., 2011. The source of early IFN- $\gamma$ that plays a role in Th1 priming. Animals.

Diomede, L., Colotta, F., Piovani, B., Re, F., Modest, E.J., Salmona, M., 1993. Induction of apoptosis in human leukemic cells by the ether lipid 1-octadecyl-2-methyl-rac-glycero-3-

Estella-Hermoso de Mendoza, A., Campanero, M.A., de la Iglesia-Vicente, J., Gajate, C., phosphocholine. A possible basis for its selective action. Int. J. Cancer 53, 124-30.

Flügel, A., Berkowicz, T., Ritter, T., Labeur, M., Jenne, D.E., Li, Z., Ellwart, J.W., Willem, green fluorescent effector cells before and during experimental autoimmune encephalomyelitis. Immunity 14, 547-60. 
1 Franciotta, D., Salvetti, M., Lolli, F., Serafini, B., Aloisi, F., 2008. B cells and multiple 2 sclerosis. Lancet Neurol. 7, 852-8.

3 Friese, M.A., Fugger, L., 2005. Autoreactive CD8+ T cells in multiple sclerosis: a new target for therapy? Brain 128, 1747-63.

Gajate, C., Fonteriz, R.I., Cabaner, C., Alvarez-Noves, G., Alvarez-Rodriguez, Y., Modolell, M., Mollinedo, F., 2000. Intracellular triggering of Fas, independently of FasL, as a new mechanism of antitumor ether lipid-induced apoptosis. Int. J. Cancer 85, 674-82.

Gajate, C., Gonzalez-Camacho, F., Mollinedo, F., 2009. Involvement of raft aggregates enriched in Fas/CD95 death-inducing signaling complex in the antileukemic action of edelfosine in Jurkat cells. PLoS One 4, e5044.

Gajate, C., Mollinedo, F., 2001. The antitumor ether lipid ET-18-OCH(3) induces apoptosis through translocation and capping of Fas/CD95 into membrane rafts in human leukemic cells. Blood 98, 3860-3.

Haas, J., Hug, A., Viehöver, A., Fritzsching, B., Falk, C.S., Filser, A., Vetter, T., Milkova, L., Korporal, M., Fritz, B., Storch-Hagenlocher, B., Krammer, P.H., Suri-Payer, E., Wildemann, B., 2005. Reduced suppressive effect of CD4+CD25high regulatory T cells on the $\mathrm{T}$ cell immune response against myelin oligodendrocyte glycoprotein in patients with multiple sclerosis. Eur. J. Immunol. 35, 3343-52.

Hauser, S.L., Waubant, E., Arnold, D.L., Vollmer, T., Antel, J., Fox, R.J., Bar-Or, A., Panzara, M., Sarkar, N., Agarwal, S., Langer-Gould, A., Smith, C.H., 2008. B-cell depletion with rituximab in relapsing-remitting multiple sclerosis. N. Engl. J. Med. 358, $676-88$. 
1 Hillert, J., Olerup, O., 1993. HLA and MS. Neurology 43, 2426-7.

2 Jersild, C., Fog, T., Hansen, G.S., Thomsen, M., Svejgaard, A., Dupont, B., 1973.

3 Histocompatibility determinants in multiple sclerosis, with special reference to clinical

$4 \quad$ course. Lancet 2, 1221-5.

5 Klein-Franke, A., Munder, P.G., 1992. Alkyllysophospholipid prevents induction of

6 experimental allergic encephalomyelitis. J. Autoimmun. 5, 83-91.

7 Kötting, J., Marschner, N.W., Neumüller, W., Unger, C., Eibl, H., 1992. Hexadecylphosphocholine and octadecyl-methyl-glycero-3-phosphocholine: a comparison of hemolytic activity, serum binding and tissue distribution. Prog. Exp. Tumor Res. 34, 131-42.

Kovarik, J., Chabannes, D., Borel, J.F., 1995. Immunoregulation and drug treatment in chronic relapsing experimental allergic encephalomylitis in the Lewis rat. Int. J. Immunopharmacol. 17, 255-263.

Linker, R.A., Rott, E., Hofstetter, H.H., Hanke, T., Toyka, K. V, Gold, R., 2005. EAE in beta2 microglobulin-deficient mice: axonal damage is not dependent on MHC-I restricted immune responses. Neurobiol. Dis. 19, 218-28.

Liu, X., Kim, C.N., Yang, J., Jemmerson, R., Wang, X., 1996. Induction of apoptotic program in cell-free extracts: requirement for dATP and cytochrome c. Cell 86, 147-57.

Lucchinetti, C.F., Brück, W., Rodriguez, M., Lassmann, H., 1996. Distinct patterns of multiple sclerosis pathology indicates heterogeneity on pathogenesis. Brain Pathol. 6, 259-74. 
1 Lundmark, F., Duvefelt, K., Iacobaeus, E., Kockum, I., Wallström, E., Khademi, M., Oturai, A., Ryder, L.P., Saarela, J., Harbo, H.F., Celius, E.G., Salter, H., Olsson, T., Hillert, J., 2007. Variation in interleukin 7 receptor alpha chain (IL7R) influences risk of multiple sclerosis. Nat. Genet. 39, 1108-13.

Martin, R., Jaraquemada, D., Flerlage, M., Richert, J., Whitaker, J., Long, E.O., McFarlin, D.E., McFarland, H.F., 1990. Fine specificity and HLA restriction of myelin basic protein-specific cytotoxic $\mathrm{T}$ cell lines from multiple sclerosis patients and healthy individuals. J. Immunol. 145, 540-8.

Martin, R., McFarland, H.F., McFarlin, D.E., 1992. Immunological aspects of demyelinating diseases. Annu. Rev. Immunol. 10, 153-87.

McElroy, J.P., Oksenberg, J.R., 2008. Multiple sclerosis genetics. Curr. Top. Microbiol. Immunol. 318, 45-72.

McGeachy, M.J., Stephens, L.A., Anderton, S.M., 2005. Natural recovery and protection from autoimmune encephalomyelitis: contribution of CD4+CD25+ regulatory cells within the central nervous system. J. Immunol. 175, 3025-32.

McRae, B.L., Miller, S.D., 1994. Fine specificity of CD4+ T cell responses to the dominant encephalitogenic PLP 139-151 peptide in SJL/J mice. Neurochem. Res. 19, 997-1004.

McRae, B.L., Vanderlugt, C.L., Dal Canto, M.C., Miller, S.D., 1995. Functional evidence for epitope spreading in the relapsing pathology of experimental autoimmune encephalomyelitis. J. Exp. Med. 182, 75-85.

Micheau, O., Tschopp, J., 2003. Induction of TNF receptor I-mediated apoptosis via two sequential signaling complexes. Cell 114, 181-90. 
1 Mollinedo, F., Fernández-Luna, J.L., Gajate, C., Martín-Martín, B., Benito, A., Martínez-

2 Dalmau, R., Modolell, M., 1997. Selective induction of apoptosis in cancer cells by the ether lipid ET-18-OCH3 (Edelfosine): molecular structure requirements, cellular uptake, and protection by Bcl-2 and Bcl-X(L). Cancer Res. 57, 1320-8.

Mollinedo, F., Martínez-Dalmau, R., Modolell, M., 1993. Early and selective induction of apoptosis in human leukemic cells by the alkyl-lysophospholipid ET-18-OCH3. Biochem. Biophys. Res. Commun. 192, 603-9.

Munder, P.G., Ferber, E., Modolell, M., Fischer, H., 1969. The influence of various adjuvants on the metabolism of phospholipids in macrophages. Int. Arch. Allergy Appl. Immunol. $36,117-28$.

Munder, P.G., Modolell, M., Ferber, E., Fischer, H., 1966. Phospholipids in quartz-damaged macrophages. Biochem. Z. 344, 310-3.

Munder, P.G., Westphal, O., 1990. Antitumoral and other biomedical activities of synthetic ether lysophospholipids. Chem. Immunol. 49, 206-35.

O’Flaherty, J.T., Wykle, R.L., Miller, C.H., Lewis, J.C., Waite, M., Bass, D.A., McCall, C.E., DeChatelet, L.R., 1981. 1-O-Alkyl-sn-glyceryl-3-phosphorylcholines: a novel class of neutrophil stimulants. Am. J. Pathol. 103, 70-8. recognition of an immunodominant myelin basic protein epitope in multiple sclerosis. Nature 346, 183-7. 
1 Pettinelli, C.B., McFarlin, D.E., 1981. Adoptive transfer of experimental allergic encephalomyelitis in SJL/J mice after in vitro activation of lymph node cells by myelin basic protein: requirement for Lyt 1+ 2- T lymphocytes. J. Immunol. 127, 1420-3.

Raine, C.S., Barnett, L.B., Brown, A., Behar, T., McFarlin, D.E., 1980. Neuropathology of experimental allergic encephalomyelitis in inbred strains of mice. Lab. Investig. 43, 1507.

Read, R.A., Moore, E.E., Moore, F.A., Carl, V.S., Banerjee, A., 1993. Platelet-activating factor-induced polymorphonuclear neutrophil priming independent of CD11b adhesion. Surgery $114,308-13$.

Richert, J.R., McFarlin, D.E., Rose, J.W., McFarland, H.F., Greenstein, J.I., 1983. Expansion of antigen-specific $\mathrm{T}$ cells from cerebrospinal fluid of patients with multiple sclerosis. J. Neuroimmunol. 5, 317-24.

Sawcer, S., Hellenthal, G., Pirinen, M., Spencer, C.C.A., Patsopoulos, N.A., Moutsianas, L., Dilthey, A., Su, Z., Freeman, C., Hunt, S.E., Edkins, S., Gray, E., Booth, D.R., Potter, S.C., Goris, A., Band, G., Oturai, A.B., Strange, A., Saarela, J., Bellenguez, C., Fontaine, B., Gillman, M., Hemmer, B., Gwilliam, R., Zipp, F., Jayakumar, A., Martin, R., Leslie, S., Hawkins, S., Giannoulatou, E., D’alfonso, S., Blackburn, H., Martinelli Boneschi, F., Liddle, J., Harbo, H.F., Perez, M.L., Spurkland, A., Waller, M.J., Mycko, M.P., Ricketts, M., Comabella, M., Hammond, N., Kockum, I., McCann, O.T., Ban, M., Whittaker, P., Kemppinen, A., Weston, P., Hawkins, C., Widaa, S., Zajicek, J., Dronov, S., Robertson, N., Bumpstead, S.J., Barcellos, L.F., Ravindrarajah, R., Abraham, R., Alfredsson, L., Ardlie, K., Aubin, C., Baker, A., Baker, K., Baranzini, S.E., Bergamaschi, L., Bergamaschi, R., Bernstein, A., Berthele, A., Boggild, M., Bradfield, J.P., Brassat, D., Broadley, S.A., Buck, D., Butzkueven, H., Capra, R., Carroll, W.M., Cavalla, P., Celius, 
E.G., Cepok, S., Chiavacci, R., Clerget-Darpoux, F., Clysters, K., Comi, G., Cossburn, M., Cournu-Rebeix, I., Cox, M.B., Cozen, W., Cree, B.A.C., Cross, A.H., Cusi, D., Daly, M.J., Davis, E., de Bakker, P.I.W., Debouverie, M., D’hooghe, M.B., Dixon, K., Dobosi, R., Dubois, B., Ellinghaus, D., Elovaara, I., Esposito, F., Fontenille, C., Foote, S., Franke, A., Galimberti, D., Ghezzi, A., Glessner, J., Gomez, R., Gout, O., Graham, C., Grant, S.F.A., Guerini, F.R., Hakonarson, H., Hall, P., Hamsten, A., Hartung, H.-P., Heard, R.N., Heath, S., Hobart, J., Hoshi, M., Infante-Duarte, C., Ingram, G., Ingram, W., Islam, T., Jagodic, M., Kabesch, M., Kermode, A.G., Kilpatrick, T.J., Kim, C., Klopp, N., Koivisto, K., Larsson, M., Lathrop, M., Lechner-Scott, J.S., Leone, M.A., Leppä, V., Liljedahl, U., Bomfim, I.L., Lincoln, R.R., Link, J., Liu, J., Lorentzen, A.R., Lupoli, S., Macciardi, F., Mack, T., Marriott, M., Martinelli, V., Mason, D., McCauley, J.L., Mentch, F., Mero, I.-L., Mihalova, T., Montalban, X., Mottershead, J., Myhr, K.M., Naldi, P., Ollier, W., Page, A., Palotie, A., Pelletier, J., Piccio, L., Pickersgill, T., Piehl, F., Pobywajlo, S., Quach, H.L., Ramsay, P.P., Reunanen, M., Reynolds, R., Rioux, J.D., Rodegher, M., Roesner, S., Rubio, J.P., Rückert, I.-M., Salvetti, M., Salvi, E., Santaniello, A., Schaefer, C.A., Schreiber, S., Schulze, C., Scott, R.J., Sellebjerg, F., Selmaj, K.W., Sexton, D., Shen, L., Simms-Acuna, B., Skidmore, S., Sleiman, P.M.A., Smestad, C., Sørensen, P.S., Søndergaard, H.B., Stankovich, J., Strange, R.C., Sulonen, A.-M., Sundqvist, E., Syvänen, A.-C., Taddeo, F., Taylor, B., Blackwell, J.M., Tienari, P., Bramon, E., Tourbah, A., Brown, M.A., Tronczynska, E., Casas, J.P., Tubridy, N., Corvin, A., Vickery, J., Jankowski, J., Villoslada, P., Markus, H.S., Wang, K., Mathew, C.G., Wason, J., Palmer, C.N.A., Wichmann, H.-E., Plomin, R., Willoughby, E., Rautanen, A., Winkelmann, J., Wittig, M., Trembath, R.C., Yaouanq, J., Viswanathan, A.C., Zhang, H., Wood, N.W., Zuvich, R., Deloukas, P., Langford, C., Duncanson, A., Oksenberg, J.R., Pericak-Vance, M.A., Haines, J.L., Olsson, T., Hillert, J., Ivinson, A.J., De Jager, P.L., Peltonen, L., Stewart, G.J., Hafler, D.A., Hauser, S.L., McVean, G., 

immune mechanisms in multiple sclerosis. Nature 476, 214-9.

Scaffidi, C., Kirchhoff, S., Krammer, P.H., Peter, M.E., 1999. Apoptosis signaling in lymphocytes. Curr. Opin. Immunol. 11, 277-85.

Schmied, M., Breitschopf, H., Gold, R., Zischler, H., Rothe, G., Wekerle, H., Lassmann, H., 1993. Apoptosis of T lymphocytes in experimental autoimmune encephalomyelitis. Evidence for programmed cell death as a mechanism to control inflammation in the brain. Am. J. Pathol. 143, 446-52.

Simpson, J.E., Newcombe, J., Cuzner, M.L., Woodroofe, M.N., 1998. Expression of monocyte chemoattractant protein- 1 and other beta-chemokines by resident glia and inflammatory cells in multiple sclerosis lesions. J. Neuroimmunol. 84, 238-49.

Sospedra, M., Martin, R., 2005. Immunology of multiple sclerosis. Annu. Rev. Immunol. 23, $683-747$.

Tsutsumi, T., Tokumura, A., Kitazawa, S., 1998. Undifferentiated HL-60 cells internalize an antitumor alkyl ether phospholipid more rapidly than resistant K562 cells. Biochim. Biophys. Acta 1390, 73-84.

Van der Luit, A.H., Budde, M., Ruurs, P., Verheij, M., van Blitterswijk, W.J., 2002. Alkyllysophospholipid accumulates in lipid rafts and induces apoptosis via raft-dependent endocytosis and inhibition of phosphatidylcholine synthesis. J. Biol. Chem. 277, 395417. 
1 Van Der Luit, A.H., Budde, M., Verheij, M., Van Blitterswijk, W.J., 2003. Different modes of

2 internalization of apoptotic alkyl-lysophospholipid and cell-rescuing

3 lysophosphatidylcholine. Biochem. J. 374, 747-53.

4 Van der Luit, A.H., Vink, S.R., Klarenbeek, J.B., Perrissoud, D., Solary, E., Verheij, M., van

Van der Sanden, M.H.M., Houweling, M., Duijsings, D., Vaandrager, A.B., van Golde, L.M.G., 2004. Inhibition of phosphatidylcholine synthesis is not the primary pathway in hexadecylphosphocholine-induced apoptosis. Biochim. Biophys. Acta 1636, 99-107.

Viglietta, V., Baecher-Allan, C., Weiner, H.L., Hafler, D.A., 2004. Loss of functional suppression by CD4+CD25+ regulatory T cells in patients with multiple sclerosis. J. Exp. Med. 199, 971-9.

Wekerle, H., Linington, C., Lassmann, H., Meyermann, R., 1986. Cellular immune reactivity within the CNS. Trends Neurosci. 8, 271-277.

Yu, P., Gregg, R.K., Bell, J.J., Ellis, J.S., Divekar, R., Lee, H., Jain, R., Waldner, H., Hardaway, J.C., Collins, M., Kuchroo, V.K., Zaghouani, H., 2005. Functions against experimental allergic encephalomyelitis upon activation with cognate antigen 1. J. Immunol.

Zamvil, S.S., Steinman, L., 1990. The T lymphocyte in experimental allergic encephalomyelitis. Annu. Rev. Immunol. 8, 579-621. 
1 Zeine, R., Owens, T., 1993. Loss rather than downregulation of CD4+ T cells as a mechanism for remission from experimental allergic encephalomyelitis. J. Neuroimmunol. 44, 1938.

Zerp, S.F., Vink, S.R., Ruiter, G.A., Koolwijk, P., Peters, E., van der Luit, A.H., de Jong, D., 5 Budde, M., Bartelink, H., van Blitterswijk, W.J., Verheij, M., 2008. Alkylphospholipids inhibit capillary-like endothelial tube formation in vitro: antiangiogenic properties of a new class of antitumor agents. Anticancer. Drugs 19, 65-75.

Zhang, X., 2004. IL-10 is involved in the suppression of experimental autoimmune encephalomyelitis by CD25+CD4+ regulatory T cells. Int. Immunol. 16, 249-256. biologically active glycerophospholipids. J. Lipid Res. 36, 1866-75. 


\section{Figure Captions}

3 Figure 1. EAE disease course in C57BL/6 and SJL mice was dependent on edelfosine treatment. (A) Whereas PBS-treated C57BL/6 mice developed the classical chronicprogressive EAE course, mice treated with edelfosine appeared to be impacted in their EAE development but also in their physical presentation due to side effects at concentrations higher than $10 \mathrm{mg} / \mathrm{kg}$ edelfosine. Clinical scores for groups of PBS-treated $(\mathrm{n}=3), 10 \mathrm{mg} / \mathrm{kg}$ edelfosine treated $(\mathrm{n}=3), 15 \mathrm{mg} / \mathrm{kg}$ edelfosine treated $(\mathrm{n}=2)$ and $25 \mathrm{mg} / \mathrm{kg}$ edelfosine treated $(\mathrm{n}=2)$ EAE mice. Note that the treatment of mice with $25 \mathrm{mg} / \mathrm{kg}$ and $15 \mathrm{mg} / \mathrm{kg}$ edelfosine led to drug-related side effects which possibly had an impact on EAE development in immunized mice that remained clinically inconspicuous. (B) The preventive administration of edelfosine every other day had no significant effect on RR-EAE clinical scores in immunized SJL mice. Depicted groups: PBS-treated $(\mathrm{n}=6), 1 \mathrm{mg} / \mathrm{kg}$ edelfosine treated $(\mathrm{n}=6)$ and $10 \mathrm{mg} / \mathrm{kg}$ edelfosine treated (n=6) EAE mice. (C) Clinical scores for groups of PBS-treated $(n=3), 1$ $\mathrm{mg} / \mathrm{kg}$ edelfosine treated $(\mathrm{n}=4)$ and $10 \mathrm{mg} / \mathrm{kg}$ edelfosine treated $(\mathrm{n}=7)$ EAE mice with administration starting at disease onset (day 11). A treatment effect could not be proved. EAE experiments are shown as mean values $\pm \mathrm{SEM} ; * \mathrm{P}<0.05, * * \mathrm{P}<0.01$ after 2 -way ANOVA. (D) No significant reduction in cumulative disease scores was determined for groups of immunized SJL mice that were treated every other day beginning at day 5 with $1 \mathrm{mg} / \mathrm{kg}$ edelfosine or $10 \mathrm{mg} / \mathrm{kg}$ edelfosine compared to PBS-treated mice. (E) The therapeutic treatment of EAE-induced SJL mice starting at disease onset (day 11) yielded cumulative disease scores that implied an edelfosine dose-dependent reduction compared to PBS-treated controls. However, significance could not be proved. The data that is based on EAE experiments whose corresponding disease courses are depicted in (B) and (C), respectively, are shown as mean values $\pm \mathrm{SEM} ; * \mathrm{P}<0.05, * * \mathrm{P}<0.01$ after post-hoc analysis. 
1 Figure 2. Edelfosine application influenced EAE in SJL mice. (A) The preventive treatment

2 of EAE-induced SJL mice with $10 \mathrm{mg} / \mathrm{kg}$ edelfosine on a daily basis ameliorated the disease

3 course: depiction of clinical scores for groups of PBS-treated $(\mathrm{n}=7), 1 \mathrm{mg} / \mathrm{kg}$ edelfosine

4 treated $(\mathrm{n}=7)$ and $10 \mathrm{mg} / \mathrm{kg}$ edelfosine treated $(\mathrm{n}=7)$ EAE mice. The EAE experiment is

5 shown as mean values $\pm \mathrm{SEM} ; * \mathrm{P}<0.05$ after 2-way ANOVA. (B) Cumulative disease scores

6 were reduced upon preventive edelfosine treatment of EAE-induced SJL mice. The daily

7 administration of $10 \mathrm{mg} / \mathrm{kg}$ edelfosine to EAE-induced SJL mice , but not the administration

8 of $1 \mathrm{mg} / \mathrm{kg}$ edelfosine, reduced the cumulative disease score compared to PBS-treated

9 controls. The data that is based on EAE experiments whose corresponding disease courses

10 are depicted in (A) are shown as mean values $\pm \mathrm{SEM} ; * \mathrm{P}<0.05$ after post-hoc analysis.

Figure 3. Increased frequency of naïve $\mathrm{CD}^{+} \mathrm{T}$ cells after treatment with $10 \mathrm{mg} / \mathrm{kg}$ 13 edelfosine. (A) Lymph node T cells of EAE-induced PBS- or edelfosine-treated SJL mice were analyzed for frequencies of $\mathrm{CD}^{+}$and $\mathrm{CD}^{+} \mathrm{T}$ cell subsets, but also for their expression of CD62L and CD44 on the cell surface. (B) $\mathrm{CD}^{+}$and $\mathrm{CD} 8^{+} \mathrm{T}$ cell frequencies remained unchanged irrespective of the treatment. (C) Increased frequencies of $\mathrm{CD}^{2} \mathrm{~L}^{+} \mathrm{CD} 44^{-}$naïve

$17 \mathrm{CD}^{+} \mathrm{T}$ cells were detected in lymph nodes of mice that received $10 \mathrm{mg} / \mathrm{kg}$ edelfosine (1.22fold). Frequencies from one representative of two independent EAE experiments ( $n=3$ for each group in each experiment), fold-changes merged from two independent EAE

$21 \mathrm{mg} / \mathrm{kg}$ edelfosine); $* \mathrm{P}<0.05$ after post-hoc analysis.

23 Figure 4. Edelfosine treatment induced the upregulation of activated caspase-3. (A) Gating 24 strategy for activated caspase- 3 in $\mathrm{CD}^{+}$and $\mathrm{CD}^{+} \mathrm{T}$ cells as well as their activated, $\mathrm{CD} 69^{+}$ 
1 descendants. (B) Representative frequencies of $\mathrm{CD}^{+}$and $\mathrm{CD} 8^{+} \mathrm{T}$ cells as well as activated

$2 \mathrm{CD}^{+}$and $\mathrm{CD}^{+} \mathrm{T}$ cells with activated caspase-3. Here, cells were prepared from lymph

3 nodes. (C) Treatment of EAE-induced mice with $10 \mathrm{mg} / \mathrm{kg}$ edelfosine resulted in a significant

4 increase in $\mathrm{CD}^{+}$and $\mathrm{CD}^{+} \mathrm{T}$ cell frequencies with activated caspase- 3 which was also found

5 for $\mathrm{CD}^{+} \mathrm{CD} 69^{+} \mathrm{T}$ cells (spleens). Frequencies from one representative of two independent

6 EAE experiments ( $\mathrm{n}=3$ for each group in each experiment), fold-changes merged from two

7 independent EAE experiments are shown as mean values \pm SEM $(\square$ PBS, $\square 1 \mathrm{mg} / \mathrm{kg}$

8 edelfosine, $10 \mathrm{mg} / \mathrm{kg}$ edelfosine); $* \mathrm{P}<0.05$ after post-hoc analysis.

9

Figure 5. Edelfosine treatment of EAE-induced mice did not compromise proliferation

11 capacity of lymph node- or spleen-derived cells. (A) After daily treatment of EAE-induced mice with either PBS or edelfosine, lymph node cells and spleen cells (not shown) were prepared, restimulated ex vivo with Con A, anti-CD3 antibody or $\operatorname{PLP}_{(139-151)}$ and cultured for $72 \mathrm{~h}$ (+ stimulus added, - controls, absence of stimulus). Each symbol represents the mean value of triplicate approaches. Results from one representative of two independent EAE experiments ( $\mathrm{n}=3$ for each group in each experiment). (B) The relative proliferative response of cells within each condition expressed as SI. Lymph node- as well as spleen-derived cells showed no significant differences comparing the SIs of cells that were prepared from mice that received PBS, $1 \mathrm{mg} / \mathrm{kg}$ edelfosine or $10 \mathrm{mg} / \mathrm{kg}$ edelfosine and challenged with the same stimulus. Graphs display merged results from two independent experiments $(n=6)$.

Figure 6. Analysis of edelfosine treatment effects on $\mathrm{T}$ cell subsets. (A) The gating strategy allows to examine $\mathrm{CD}^{+}$and $\mathrm{CD}^{+}{ }^{\mathrm{T}}$ cell frequencies as well as $\mathrm{CD} 4^{+} \mathrm{CD} 25^{+} \mathrm{Foxp} 3^{+}$nTregs. Treatment of mice with $10 \mathrm{mg} / \mathrm{kg}$ edelfosine resulted in a reduced frequency of $\mathrm{CD}^{+} \mathrm{T}$ cells in the CNS in the acute phase of EAE compared to treatment with PBS or $1 \mathrm{mg} / \mathrm{kg}$ edelfosine. 
$1 \mathrm{mg} / \mathrm{kg}$ edelfosine in comparison to PBS-treated mice. Frequencies from one EAE experiment

2 ( $n=4$ for each group, except PBS-treated group: $n=3$ ), frequencies are shown as mean values \pm 3 SEM ( $\square$ PBS, $\square 1 \mathrm{mg} / \mathrm{kg}$ edelfosine, $10 \mathrm{mg} / \mathrm{kg}$ edelfosine); $* \mathrm{P}<0.05, * * \mathrm{P}<0.01$ after

4 post-hoc analysis.

6 Figure 7. Edelfosine treatment affected cytokine production of $\mathrm{T}$ lymphocytes. (A) The 7 production of IFN- $\gamma$ and IL-17 by $\mathrm{CD}^{+}$or $\mathrm{CD}^{+} \mathrm{T}$ cells was analyzed after intracellular cytokine staining. Dead cells were excluded. (B) The treatment of mice with $10 \mathrm{mg} / \mathrm{kg}$ edelfosine led to a decrease in frequencies of IFN- $\gamma$-producing $\mathrm{CD}^{+} \mathrm{T}$ cells compared to PBS-treated and $1 \mathrm{mg} / \mathrm{kg}$ edelfosine-treated mice. For IL-17-producing $\mathrm{CD}^{+} \mathrm{T}$ cells the P11 value was 0.0463 , but no differences between groups were found in post-hoc analysis. 12 Frequencies from one EAE experiment ( $n=4$ for each group, except PBS-treated group: $n=3$ ), frequencies are shown as mean values \pm SEM PBS, $1 \mathrm{mg} / \mathrm{kg}$ edelfosine, 10 $\mathrm{mg} / \mathrm{kg}$ edelfosine); $* \mathrm{P}<0.05, * * \mathrm{P}<0.01$ after post-hoc analysis.

Figure 8. Increased caspase-3 activation upon application of edelfosine. (A) CD4, CD8 and CD69 allowed the investigation of caspase-3 activation induced by edelfosine treatment. (B) $\mathrm{CD}^{+} \mathrm{T}$ cells with activated caspase-3 showed that treatment with $10 \mathrm{mg} / \mathrm{kg}$ edelfosine increased the frequency of this apoptosis-indicative population compared to respective cells from PBS-treated mice. Frequencies from one EAE experiment ( $\mathrm{n}=4$ for each group, except PBS-treated group: $n=3)$, frequencies are shown as mean values \pm SEM ( PBS, $\mathrm{mg} / \mathrm{kg}$ edelfosine,

$10 \mathrm{mg} / \mathrm{kg}$ edelfosine); ${ }^{\mathrm{P}}<0.05$ after post-hoc analysis.

Figure 9. Reduction of $\mathrm{NeuN}^{+}$neurons in the acute phase was prevented by edelfosine. (A) Immunized SJL mice were treated daily with PBS or edelfosine. CNS was prepared at day 14. The EAE course revealed a significant treatment effect with differences between PBS-treated 
1 mice and mice that received either $1 \mathrm{mg} / \mathrm{kg}$ or $10 \mathrm{mg} / \mathrm{kg}$ edelfosine (day 11 to 13). (B) For

2 each mouse, six sections of the cervical spinal cord were stained using an anti-NeuN

3 antibody. Per section two photographs were evaluated for each of the two ventral horns.

$4 \mathrm{NeuN}^{+}$neurons were counted to determine means. Compared to non-immunized, age-matched

5 SJL mice PBS-treated EAE mice showed a reduced number of $\mathrm{NeuN}^{+}$neurons. This reduction

6 could be prevented by treatment with either $1 \mathrm{mg} / \mathrm{kg}$ or $10 \mathrm{mg} / \mathrm{kg}$ edelfosine. (C)

7 Representative photographs of cervical spinal cord sections stained for $\mathrm{NeuN}^{+}$neurons after

8 treatment with either PBS, $1 \mathrm{mg} / \mathrm{kg}$ or $10 \mathrm{mg} / \mathrm{kg}$ edelfosine (scale bar represents $100 \mu \mathrm{m}$,

9 magnification: $20 x)$.

11 Supplementary Figure 1. Analysis of leukocyte subset frequencies. The specific expression

12 of cell surface markers allowed discrimination between cell types as exemplified by this gating strategy depicting lymph node cells from an EAE-induced, $10 \mathrm{mg} / \mathrm{kg}$ edelfosine-treated mouse. Frequencies were determined by relating the detected number of events within the respective gate to the measured number of $\mathrm{CD} 45^{+}$events.

Supplementary Figure 2. Quantification of immune cell infiltration at the acute phase of EAE. (A) The acute phase of EAE was accompanied by a maximal clinical impairment of mouse movement. PBS-treated mice showed the expected development of EAE whereas the treatment of mice with $1 \mathrm{mg} / \mathrm{kg}$ edelfosine or $10 \mathrm{mg} / \mathrm{kg}$ edelfosine resulted in milder clinical

21 EAE scores. In detail, a significant treatment effect was found with significant differences 22 between PBS-treated and $1 \mathrm{mg} / \mathrm{kg}$ edelfosine-treated groups (day 14, 15) as well as between PBS-treated and $10 \mathrm{mg} / \mathrm{kg}$ edelfosine-treated groups (day 13 to 15 ). (B) Infiltrating CD45 immune cells into brains and spinal cords were prepared and quantified by flow cytometry. (C) Quantification of CNS-infiltrating CD45 ${ }^{+}$leukocytes was performed by flow cytometry using BD Trucount tubes according to the displayed gating strategy. CD45 ${ }^{+}$events were 
1 related to detected bead events in the Fl-1/Fl-2-defined gate and the absolute number of

2 infiltrating cells was calculated using the absolute bead number. (D) The treatment with 10

$3 \mathrm{mg} / \mathrm{kg}$ edelfosine led to a significant reduction in $\mathrm{T}$ cell frequencies compared to $\mathrm{PBS}$

4 treatment. Frequencies from one EAE experiment $(n=4$ for each group, except PBS-treated

5 group: $\mathrm{n}=3$ ), frequencies are shown as mean values \pm SEM $(\square$ PBS, $\square 1 \mathrm{mg} / \mathrm{kg}$

6 edelfosine, $10 \mathrm{mg} / \mathrm{kg}$ edelfosine); $* \mathrm{P}<0.05$ after post-hoc analysis.

7

8 Supplementary Figure 3. Identification of infiltrating cells into the CNS of EAE-induced

9 SJL mice in the acute phase due to the expression of characteristic surface marker molecules.

10 After the separation of CD $45^{\text {int }}$ CNS-residing microglia from CD $45^{\text {high }}$ infiltrating leukocytes,

11 the latter population was further specified (leukocyte subsets) as exemplified by this gating

12 strategy depicting cells from an EAE-induced, $10 \mathrm{mg} / \mathrm{kg}$ edelfosine-treated mouse. 

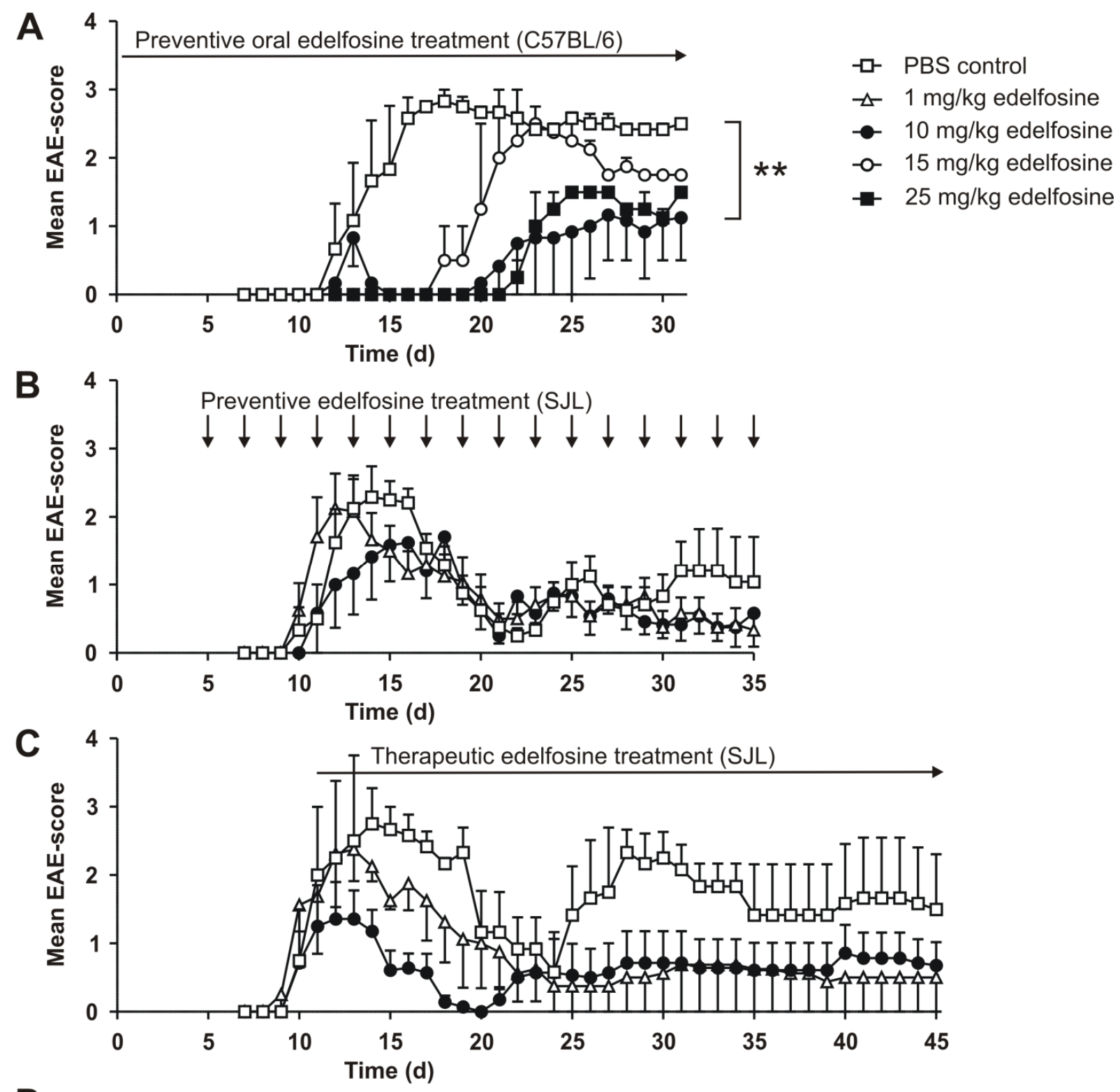

D Preventive edelfosine treatment (SJL)

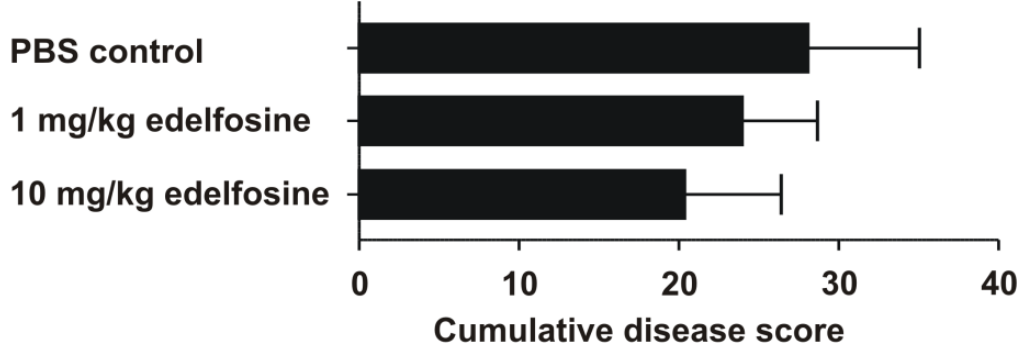

E Therapeutic edelfosine treatment (SJL)

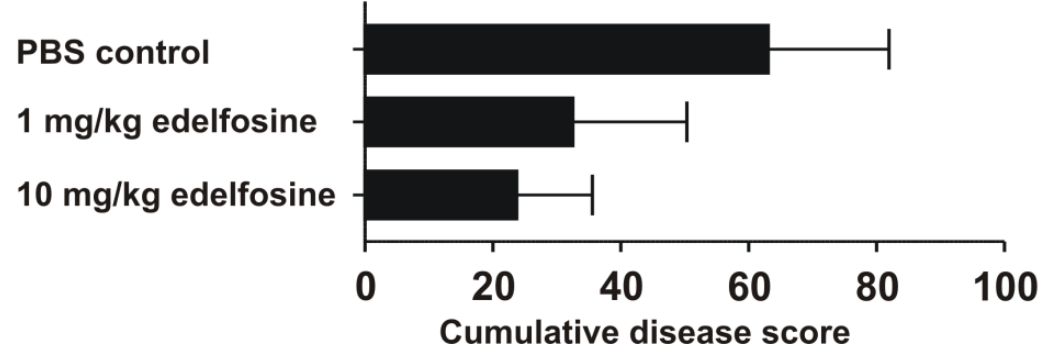


A

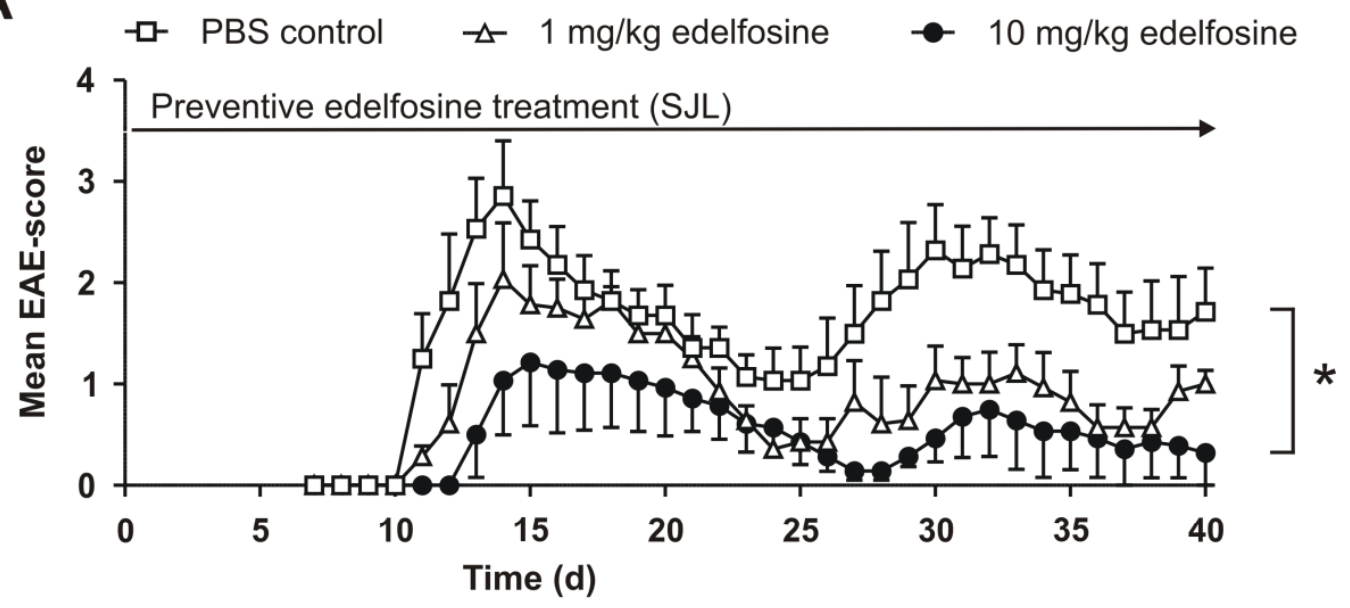

B Preventive edelfosine treatment (SJL)

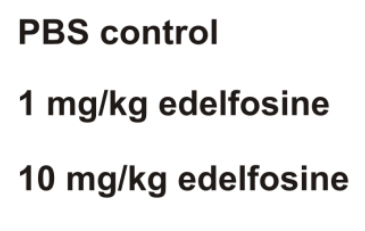

1

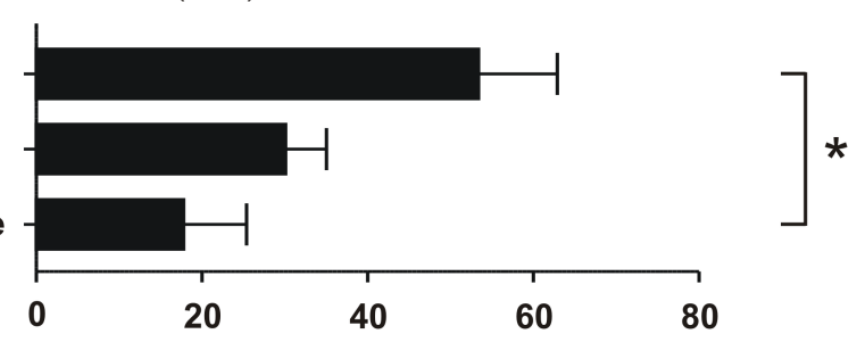

Cumulative disease score 
A

$10 \mathrm{mg} / \mathrm{kg}$ Edelfosine
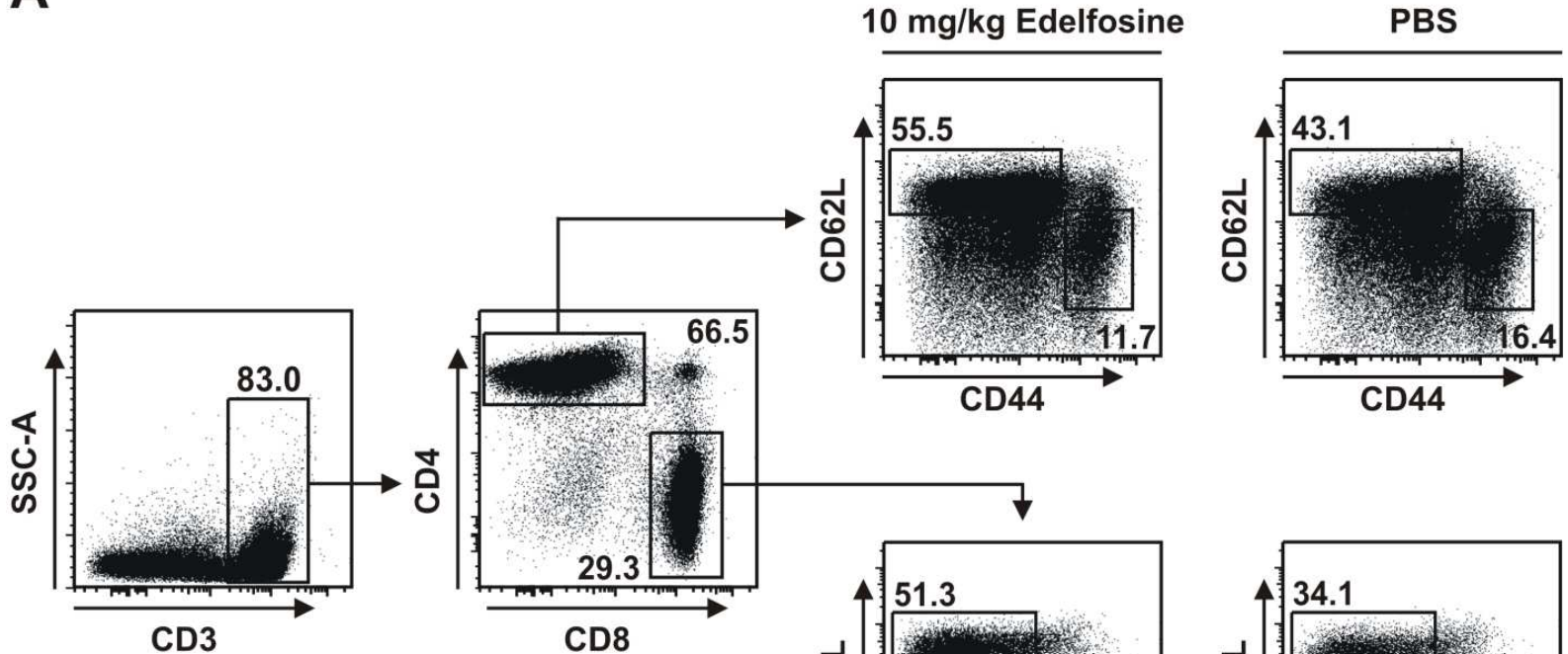

ญิ

55.5

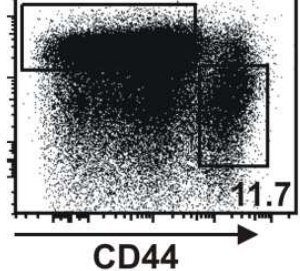

ฟัญ

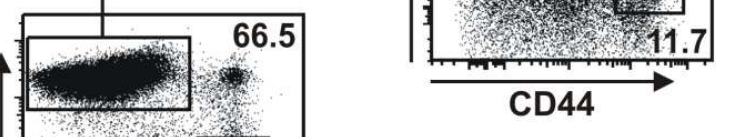

CD44

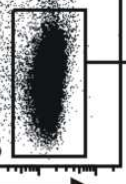

CD8
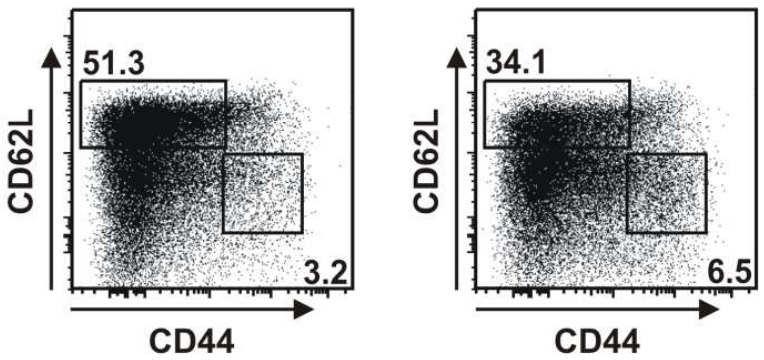

B

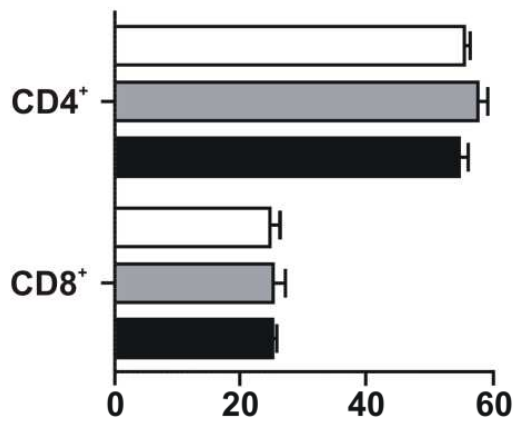

Frequency [\% of gated cells]

C
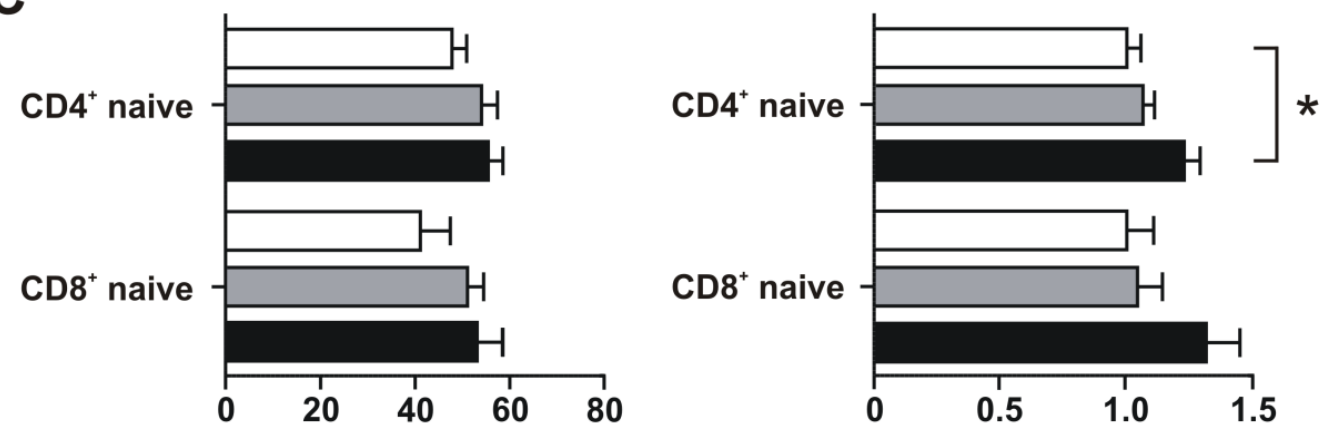

Frequency [\% of CD4/8 ${ }^{+}$cells]

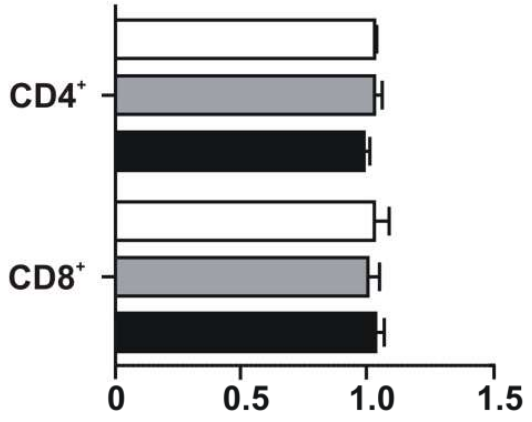

Fold-change

Fold-change 
A
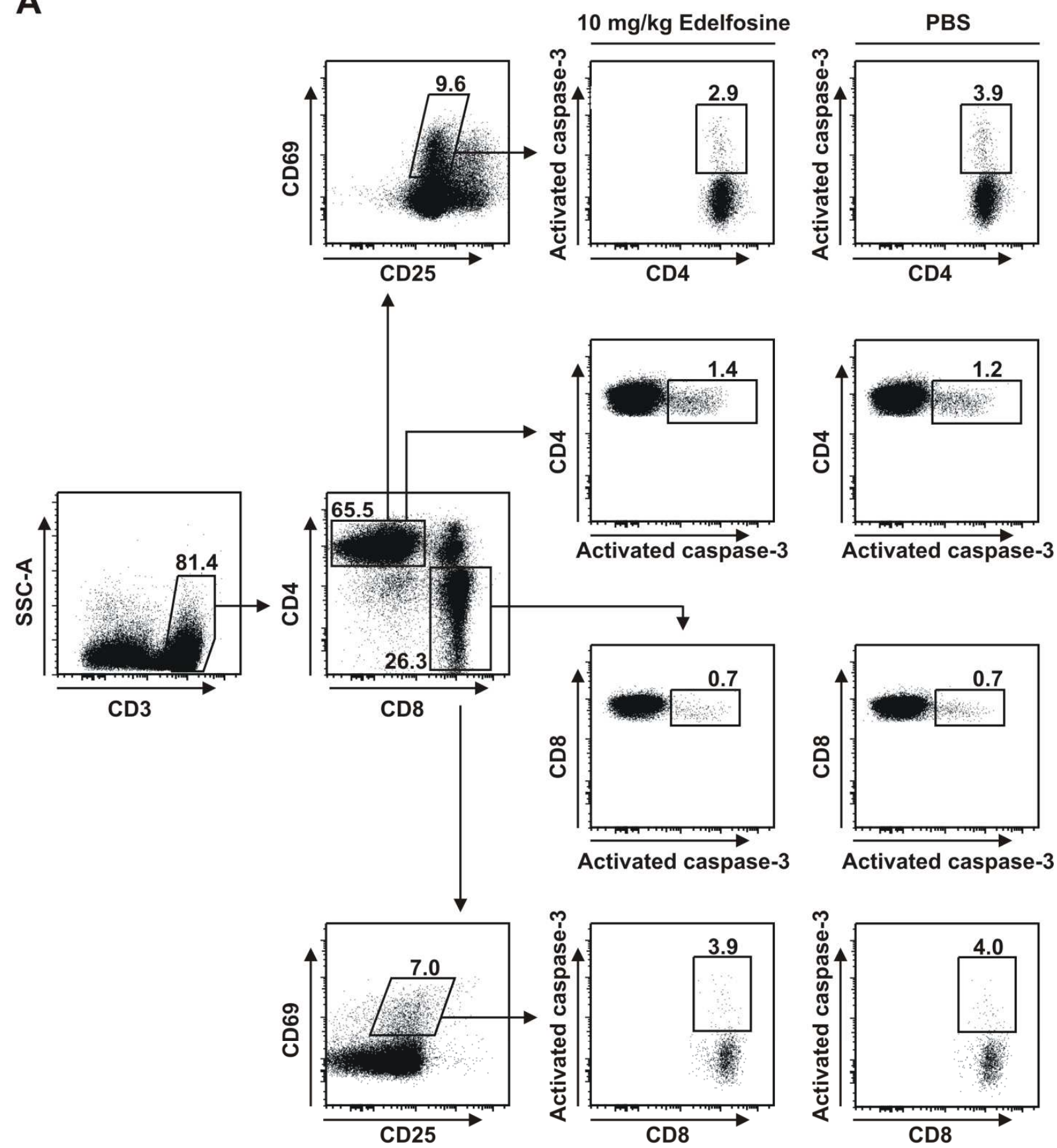

B
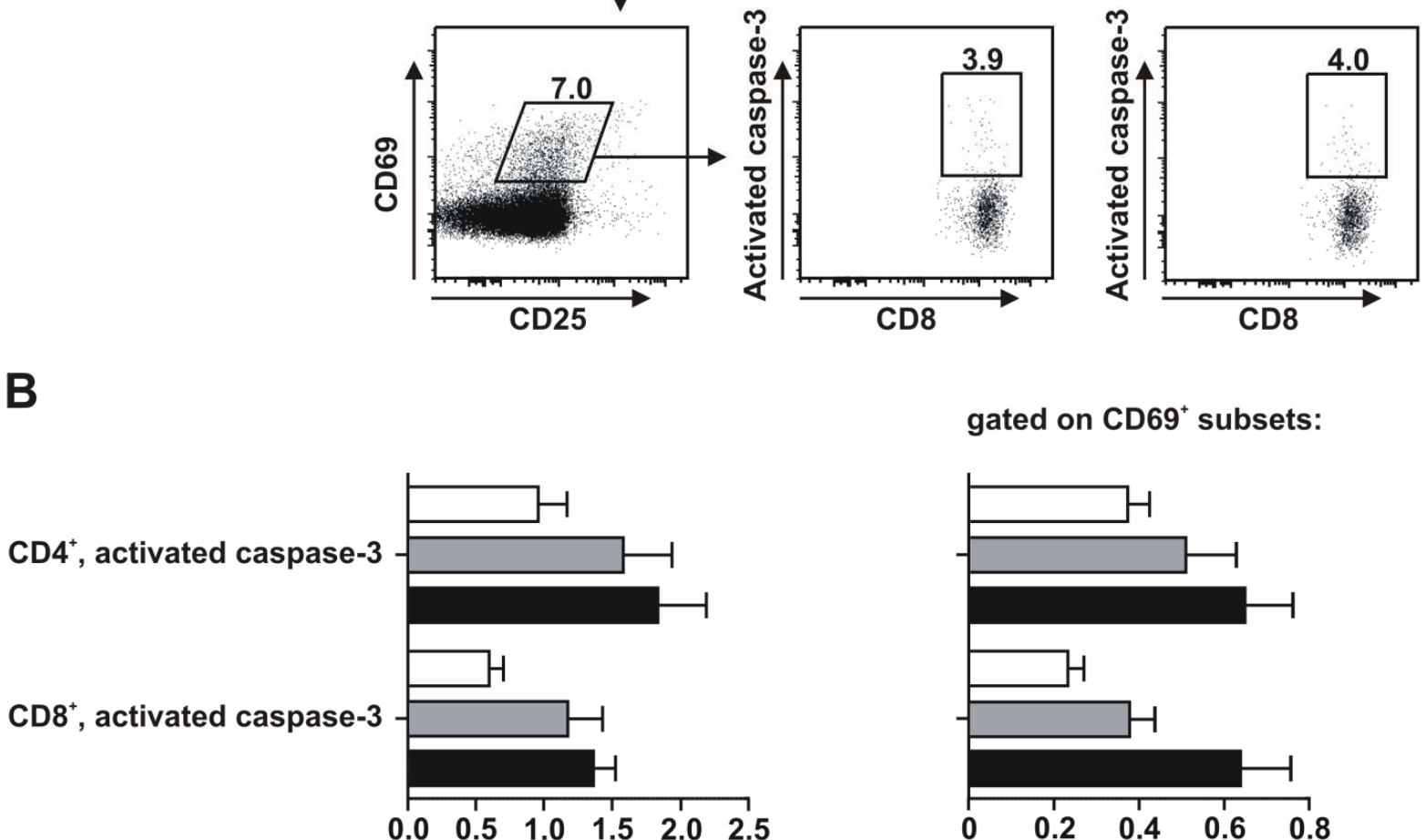

gated on $\mathrm{CD}^{+} 9^{+}$subsets:

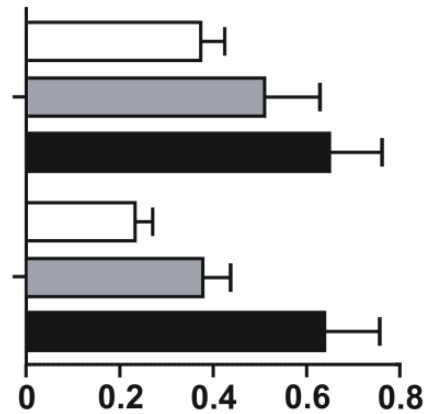

frequency $\left[\%\right.$ of $C D 4 / 8^{+}$cells] 


\section{C}

spleen:

gated on $\mathrm{CD}^{2} 9^{+}$subsets:
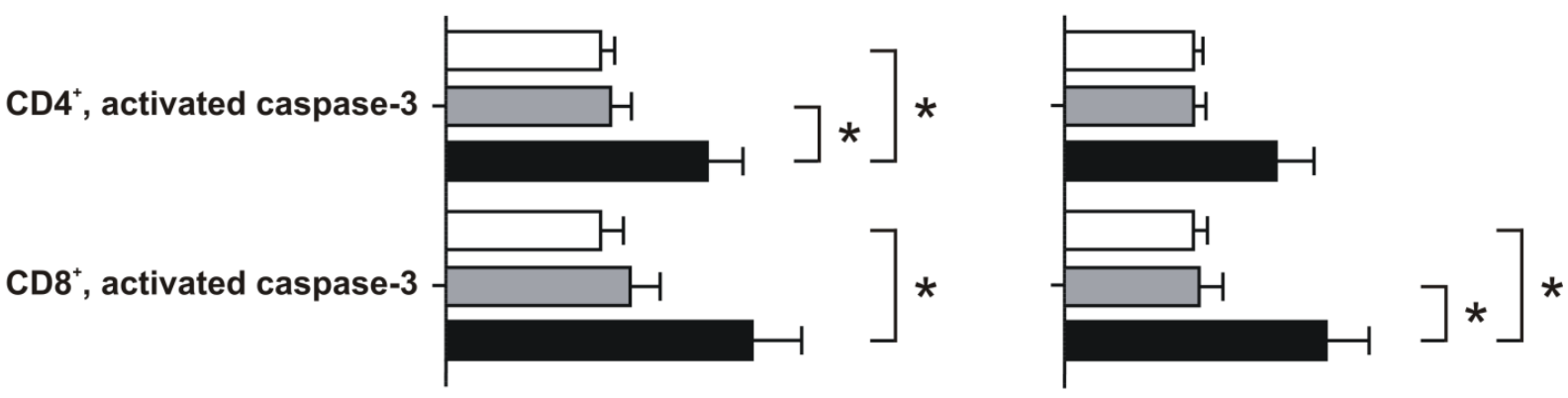

lymph nodes:
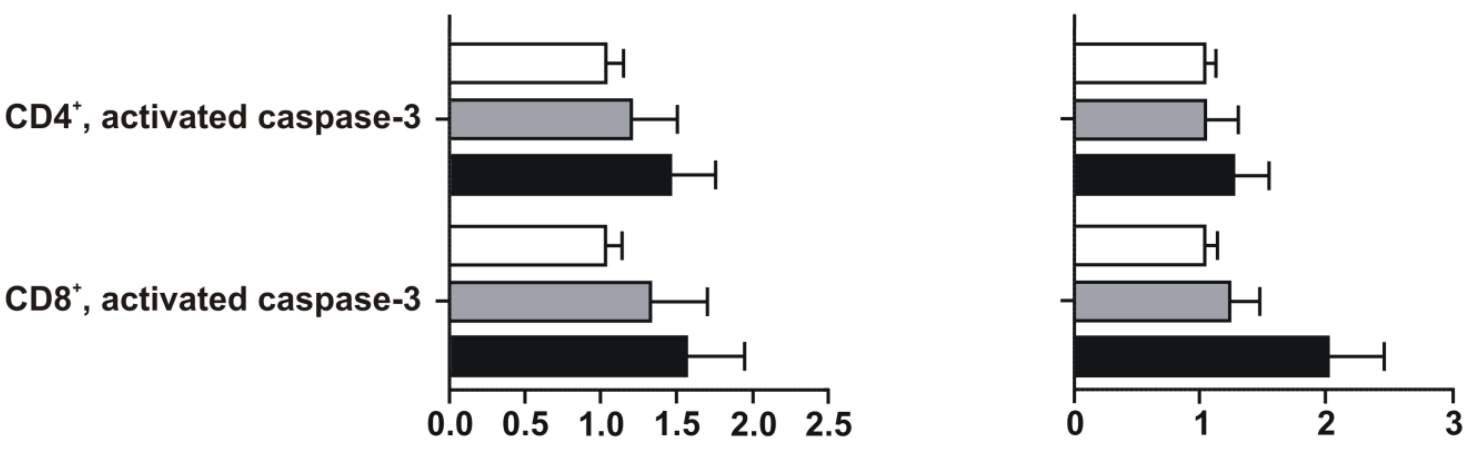

Fold-change

Fold-change 
A

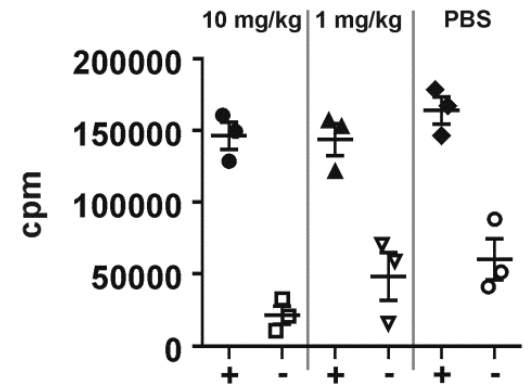

$5 \mu \mathrm{g} / \mathrm{ml}$ Con A

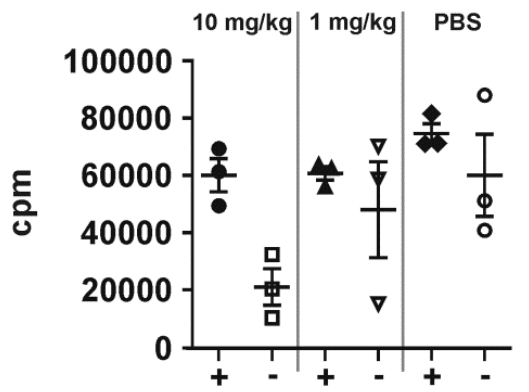

$0.5 \mu \mathrm{g} / \mathrm{ml}$ anti-CD3

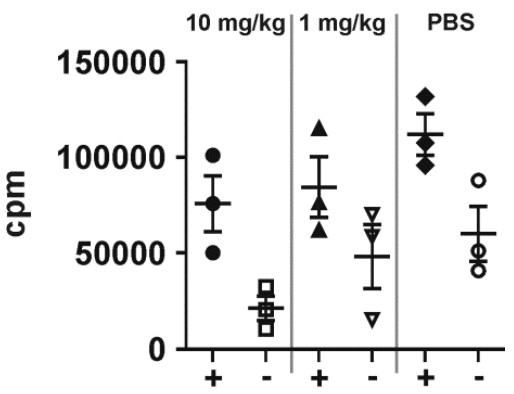

$1 \mu \mathrm{g} / \mathrm{ml} \operatorname{PLP}_{(139-151)}$

B

lymph nodes:

$5 \mu \mathrm{g} / \mathrm{ml}$ Con A

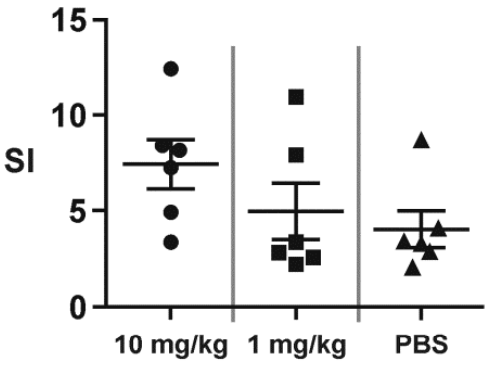

spleen:

$5 \mu \mathrm{g} / \mathrm{ml}$ Con A

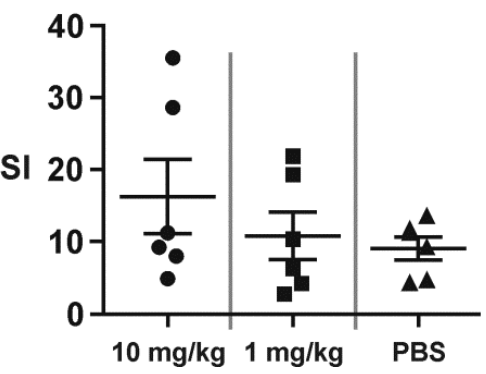

$0.5 \mu \mathrm{g} / \mathrm{ml}$ anti-CD3

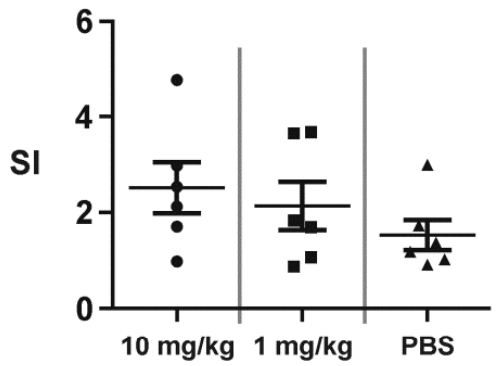

$0.5 \mu \mathrm{g} / \mathrm{ml}$ anti-CD3

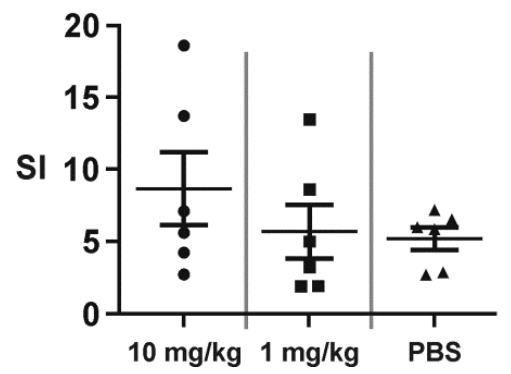

SI

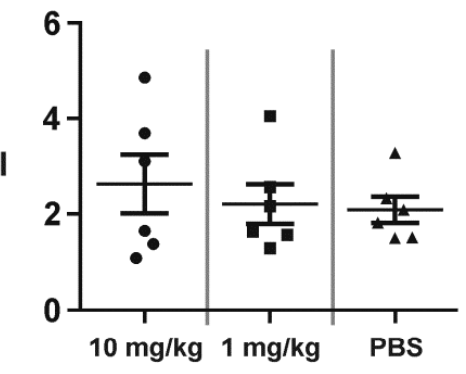

SI

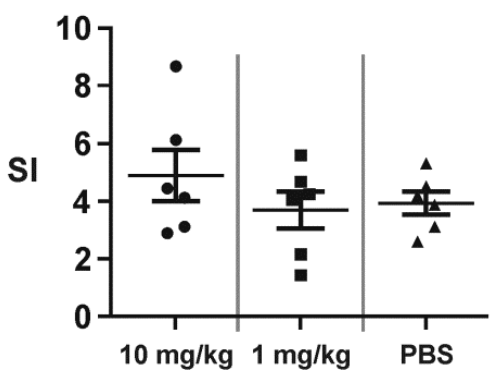


A
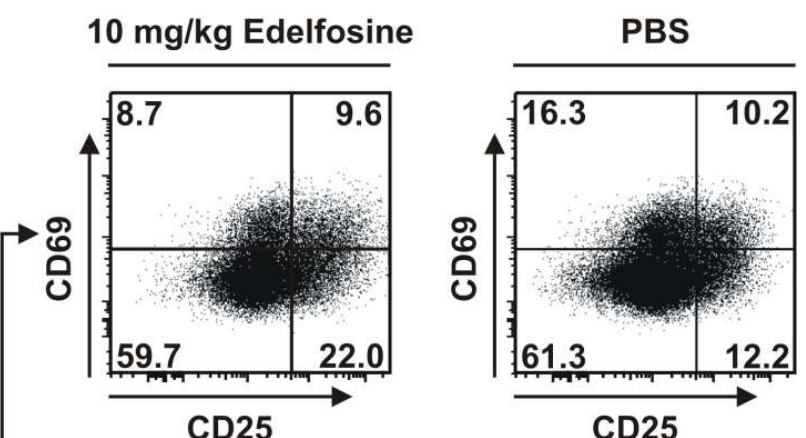

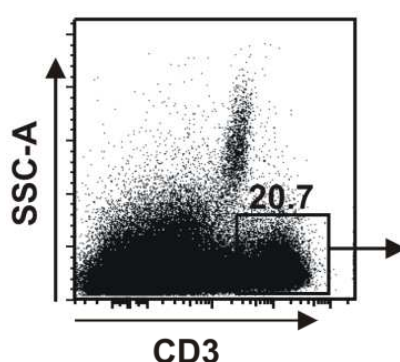

B

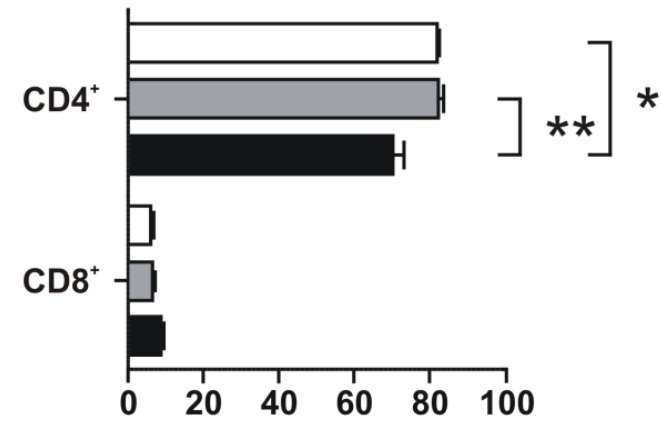

Frequency [\% of $\mathrm{CD}^{+}$cells]
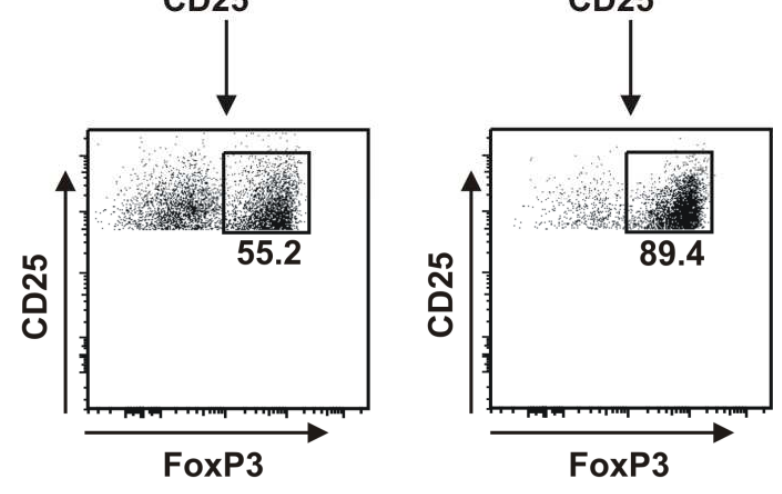

$\mathrm{CD}^{+} \mathrm{CD}^{+} 5^{+}$Foxp3 $^{+}$

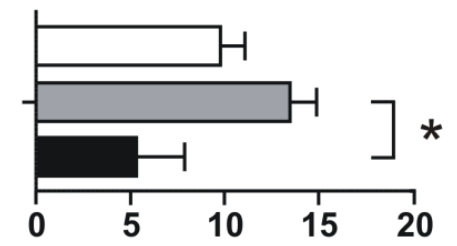

Frequency [\% of $\mathrm{CD} 4^{+}$cells] 
A

A $10 \mathrm{mg} / \mathrm{kg}$ Edelfosine
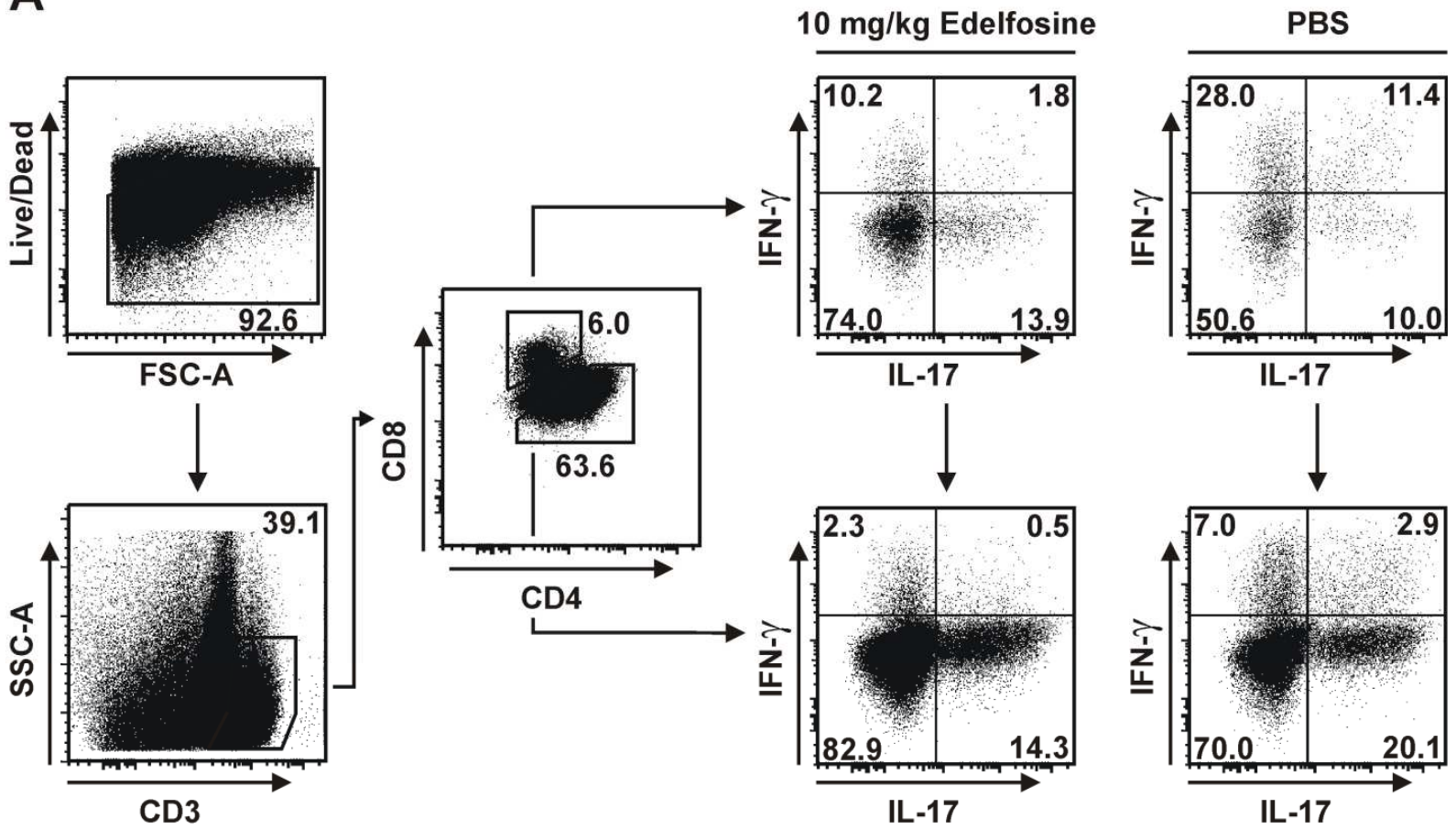

B
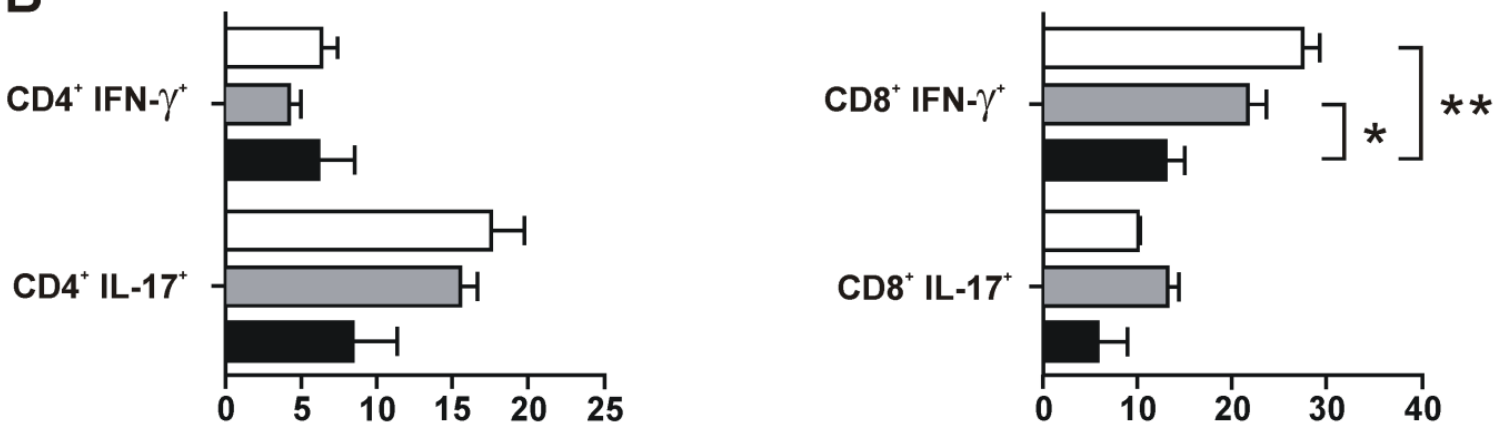

Frequency [\% of $\mathrm{CD} 4^{+}$cells]

Frequency [\% of $\mathrm{CD}^{+}$cells] 


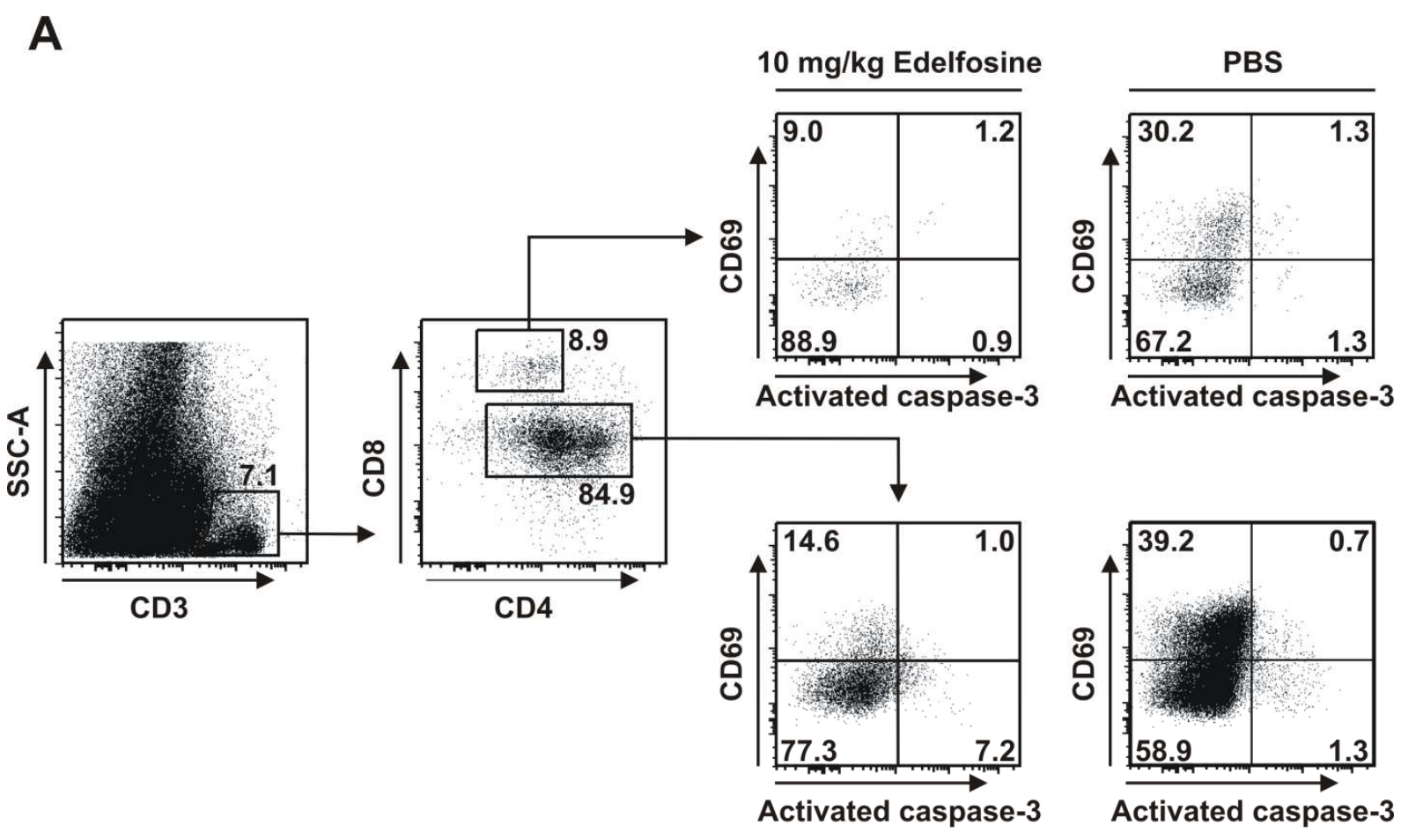

B

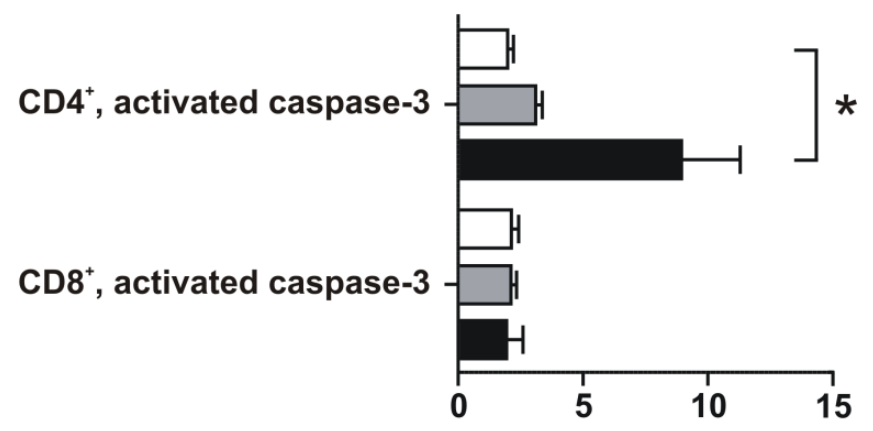

gated on $\mathrm{CD}^{+} 9^{+}$subsets: 
A

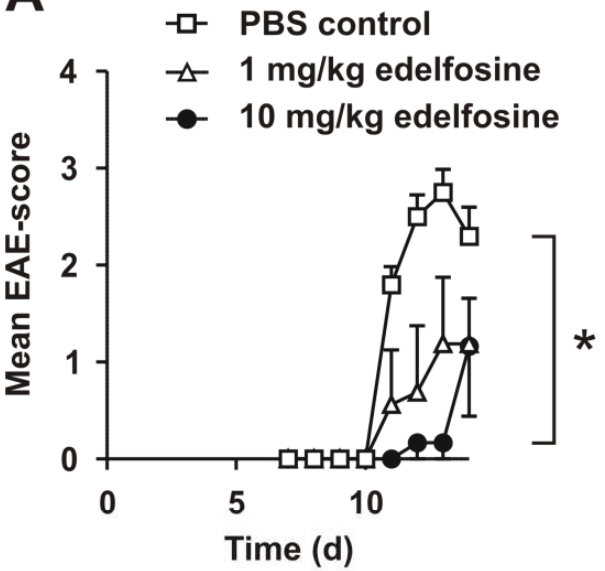

C

PBS control

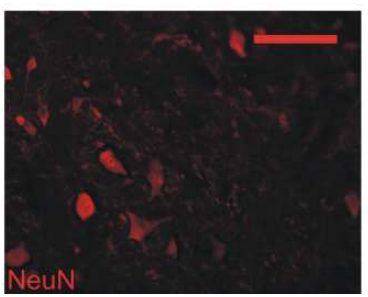

B

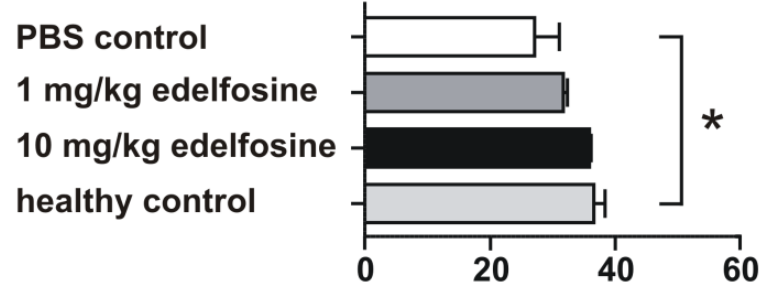

Number of $\mathrm{NeuN}^{+}$cells / section
$1 \mathrm{mg} / \mathrm{kg}$ edelfosine

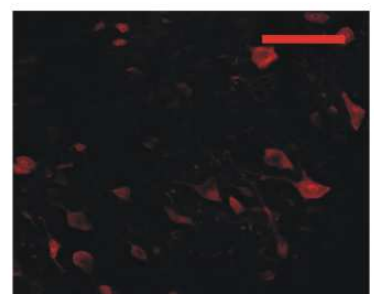

$10 \mathrm{mg} / \mathrm{kg}$ edelfosine

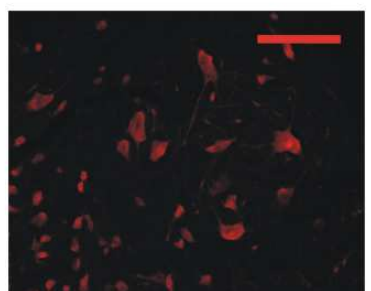

healthy control

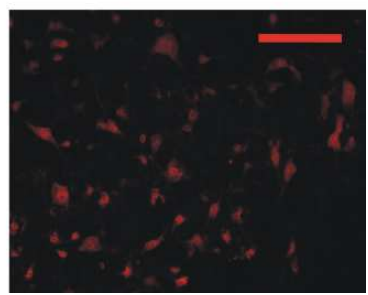




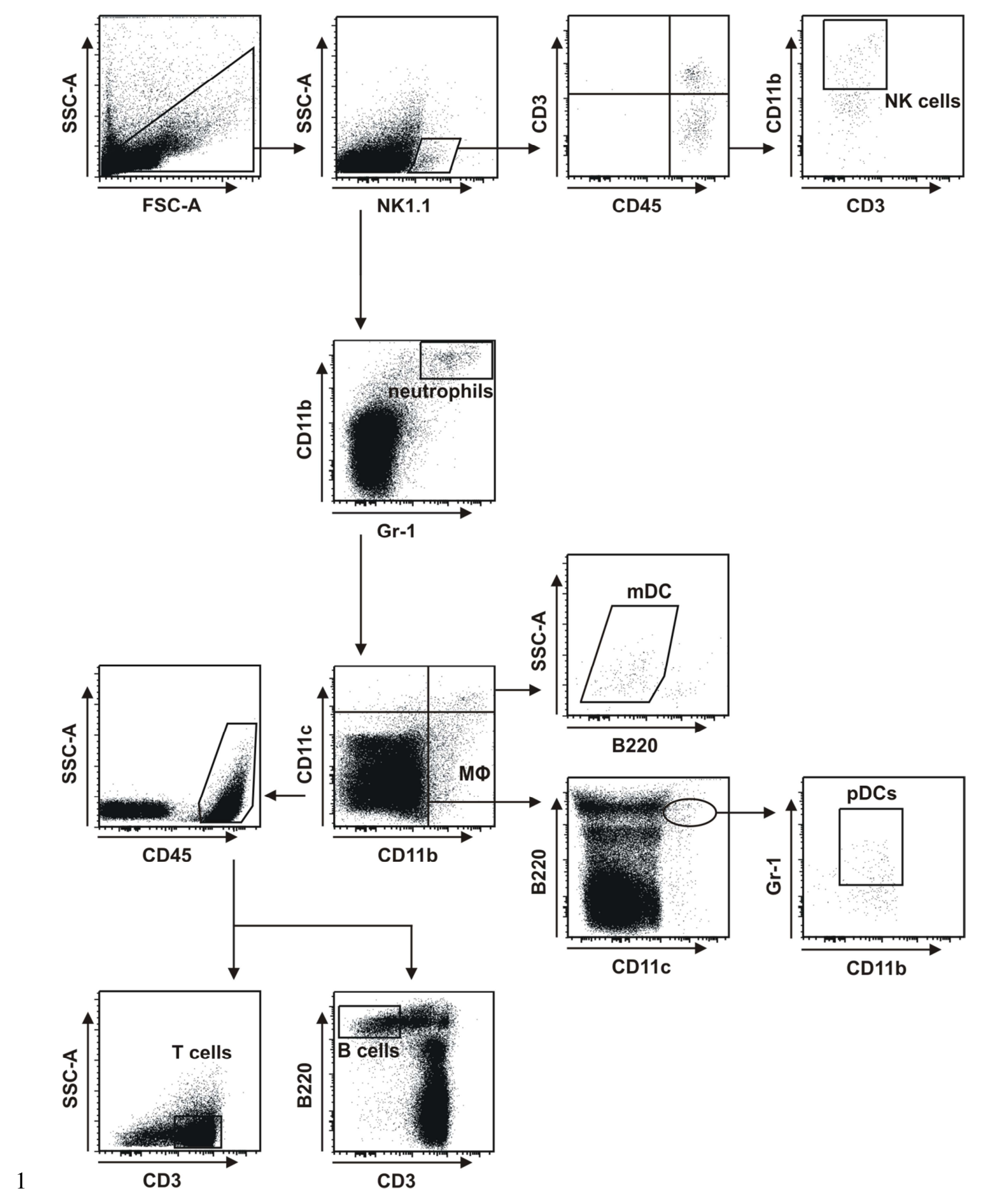


A

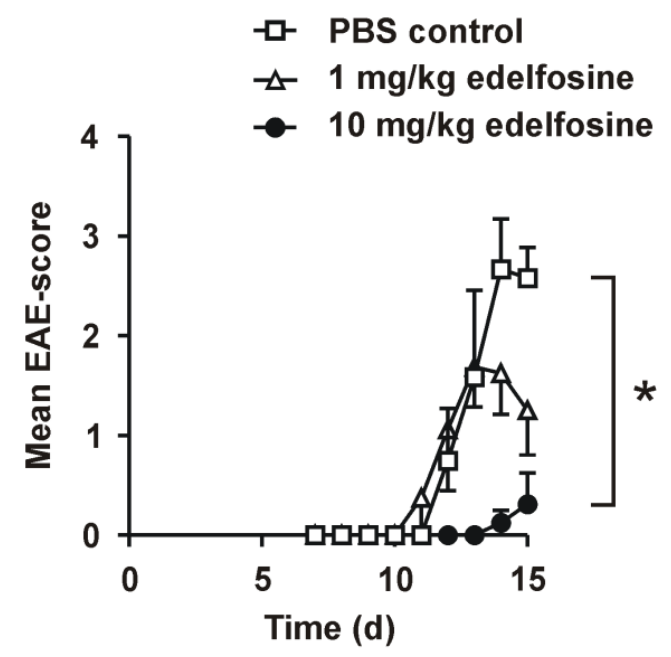

B

Absolute cell count

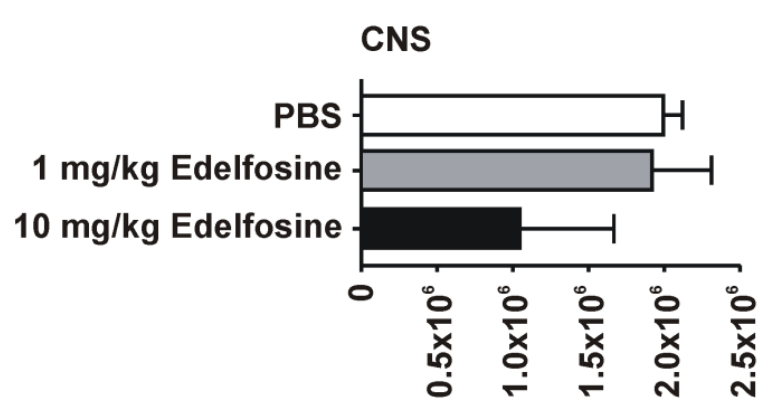

C

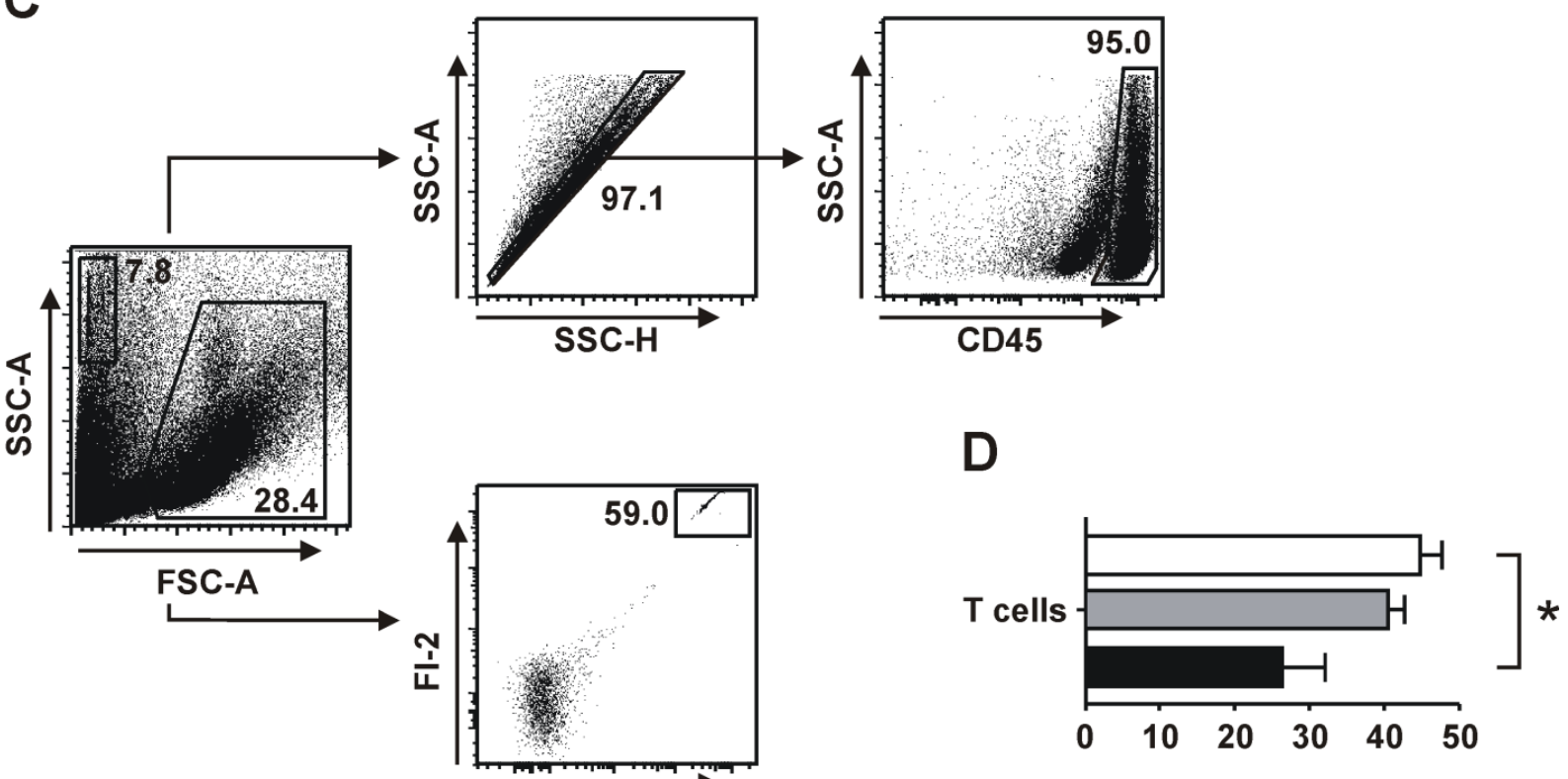

$\mathrm{FI}-1$

Frequency [\% of $\mathrm{CD}^{4} 5^{+}$cells] 

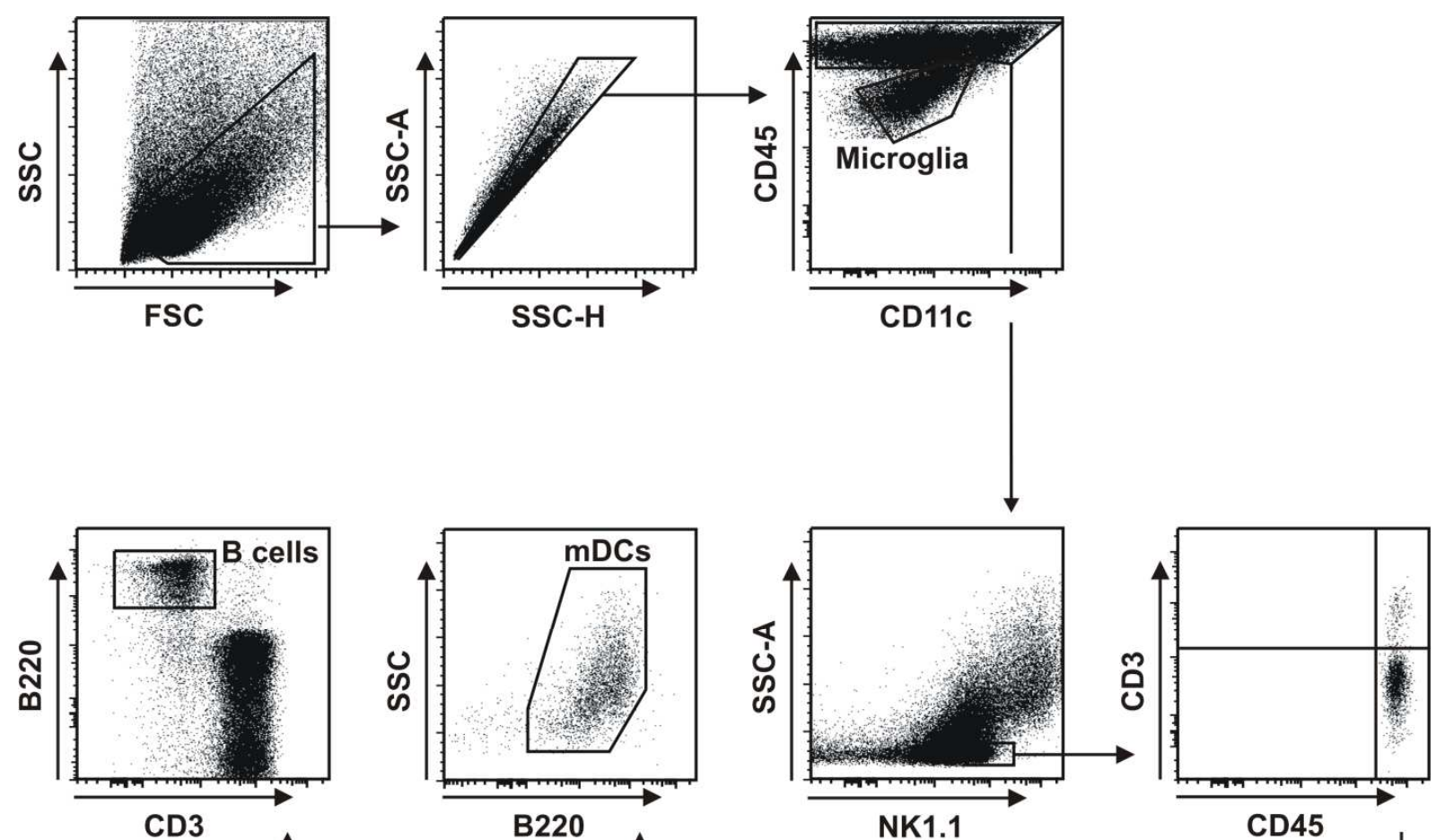

1
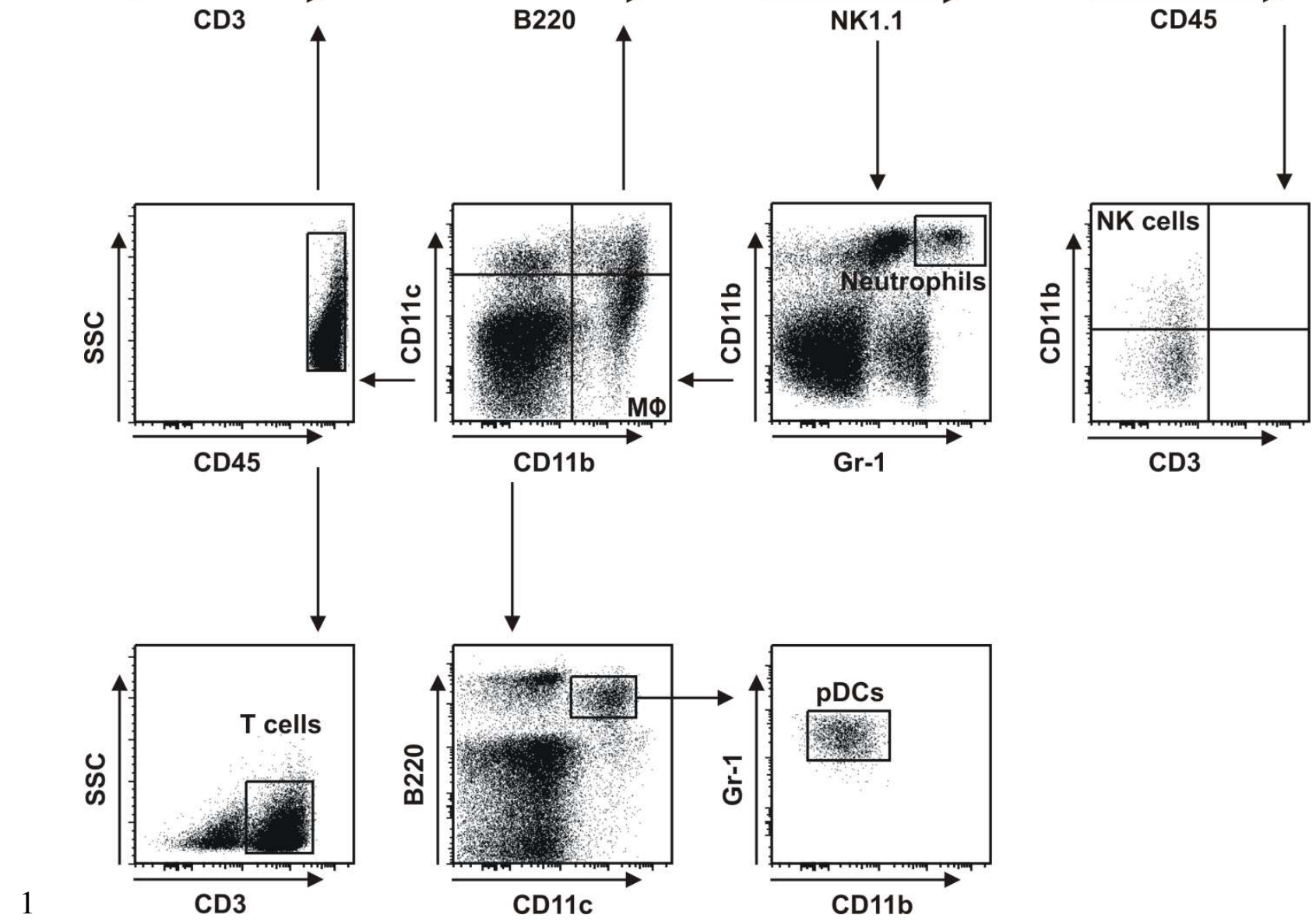